\title{
Controls and Adaptive Management of Nitrification in Agricultural Soils
}

\author{
Jeanette Norton ${ }^{1 *}$ and Yang Ouyang ${ }^{2}$ \\ ${ }^{1}$ Department of Plants, Soils and Climate, Utah State University, Logan, UT, United States, ${ }^{2}$ Department of Microbiology and \\ Plant Biology, Institute of Environmental Genomics, University of Oklahoma, Norman, OK, United States
}

Agriculture is responsible for over half of the input of reactive nitrogen $(\mathrm{N})$ to terrestrial systems; however improving $\mathrm{N}$ availability remains the primary management technique to increase crop yields in most regions. In the majority of agricultural soils, ammonium is rapidly converted to nitrate by nitrification, which increases the mobility of $\mathrm{N}$ through the soil matrix, strongly influencing $\mathrm{N}$ retention in the system. Decreasing nitrification through management is desirable to decrease $\mathrm{N}$ losses and increase $\mathrm{N}$ fertilizer use efficiency. We review the controlling factors on the rate and extent of nitrification in agricultural soils from temperate regions including substrate supply, environmental conditions, abundance and diversity of nitrifiers and plant and microbial interactions with nitrifiers. Approaches to the management of nitrification include those that control ammonium

OPEN ACCESS

Edited by:

Suvendu Das,

Gyeongsang National University,

South Korea

Reviewed by:

$\mathrm{Jim} \mathrm{He}$,

University of Chinese Academy of

Sciences, China

Yun-Feng Duan,

Aarhus University, Denmark

${ }^{*}$ Correspondence: Jeanette Norton jeanette.norton@usu.edu

Specialty section

This article was submitted to Terrestrial Microbiology, a section of the journal

Frontiers in Microbiology

Received: 19 January 2019 Accepted: 06 August 2019

Published: 30 August 2019

Citation:

Norton J and Ouyang Y (2019) Controls and Adaptive Management of Nitrification in Agricultural Soils.

Front. Microbiol. 10:1931.

doi: 10.3389/fmicb.2019.01931 substrate availability and those that inhibit nitrifiers directly. Strategies for controlling ammonium substrate availability include timing of fertilization to coincide with rapid plant update, formulation of fertilizers for slow release or with inhibitors, keeping plant growing continuously to assimilate $\mathrm{N}$, and intensify internal $\mathrm{N}$ cycling (immobilization). Another effective strategy is to inhibit nitrifiers directly with either synthetic or biological nitrification inhibitors. Commercial nitrification inhibitors are effective but their use is complicated by a changing climate and by organic management requirements. The interactions of the nitrifying organisms with plants or microbes producing biological nitrification inhibitors is a promising approach but just beginning to be critically examined. Climate smart agriculture will need to carefully consider optimized seasonal timing for these strategies to remain effective management tools.

Keywords: nitrification, global change, ammonia oxidizers, nitrite oxidizers, biological nitrification inhibition, agricultural management

\section{INTRODUCTION}

Human activities have dramatically altered the global nitrogen $(\mathrm{N})$ cycle by increasing the amount of reactive $\mathrm{N}$ in the biosphere (Kaiser, 2001; Fowler et al., 2013). The anthropogenic inputs of industrially produced $\mathrm{N}$ fertilizers and $\mathrm{N}$ fixation by crops now exceed the natural $\mathrm{N}$ inputs to terrestrial systems (Galloway and Cowling, 2002; Schlesinger, 2009; Fowler et al., 2013). Yet the $\mathrm{N}$ use efficiency (NUE) of our fertilizers in agricultural systems remains quite low, typically only about $50 \%$ or less of fertilizer $\mathrm{N}$ applied is taken up by the crop during the growing season (Raun and Schepers, 2008; Cavigelli et al., 2012). A better understanding of $\mathrm{N}$ cycling in agroecosystems is essential for intensifying sustainable food production while decreasing negative environmental impacts. Overall, improved management of nitrification may increase the NUE of fertilization while 
reducing the transport of reactive $\mathrm{N}$ to rivers and groundwater and the emissions of greenhouse gases especially nitrous oxide $\left(\mathrm{N}_{2} \mathrm{O}\right)$ (Smith et al., 2008; Robertson and Vitousek, 2009). These are important considerations for agricultural and environmental policy especially as global climate change intensifies (Schlesinger, 2009; Cavigelli et al., 2012; Robertson et al., 2014).

Agriculture is responsible for over half of the input of reactive $\mathrm{N}$ to terrestrial systems; however improving $\mathrm{N}$ availability through fertilization remains a primary management technique to increase crop yields in most regions. $\mathrm{N}$ fertility management is inherently complex because available $\mathrm{N}$ is temporally and spatially dynamic and subject to high rates of loss through diverse pathways. Mobility and availability of $\mathrm{N}$ from fertilizers and organic sources is the result of microbial enzymatic processes especially mineralization and nitrification operating within the physical and chemical constraints of the soil matrix (Figure 1). In many agricultural systems, large amounts of fertilizer $\mathrm{N}$ are lost from the root zone as nitrate through leaching and denitrification (Robertson et al., 2013). Avoiding the combination of high external inputs with low resource use efficiency remains a major concern for the sustainability of $\mathrm{N}$ in agroecosystems (Spiertz, 2010).

Nitrification is the biological oxidation of ammonia $\left(\mathrm{NH}_{3}\right)$ or ammonium $\left(\mathrm{NH}_{4}^{+}\right)$to oxidized $\mathrm{N}$ in the form of nitrite $\left(\mathrm{NO}_{2}^{-}\right)$ and further to nitrate $\left(\mathrm{NO}_{3}^{-}\right)$. In the majority of agricultural soils, $\mathrm{NH}_{4}^{+}$is rapidly converted to $\mathrm{NO}_{3}^{-}$, which may accumulate in the soil solution to high concentrations. Conversion of the cation, $\mathrm{NH}_{4}^{+}$, to an anion $\left(\mathrm{NO}_{2}^{-}\right.$or $\left.\mathrm{NO}_{3}^{-}\right)$determines the movement of $\mathrm{N}$ through the generally negatively charged soil matrix and therefore strongly influences the fate of $\mathrm{N}$ in the soil. Nitrate

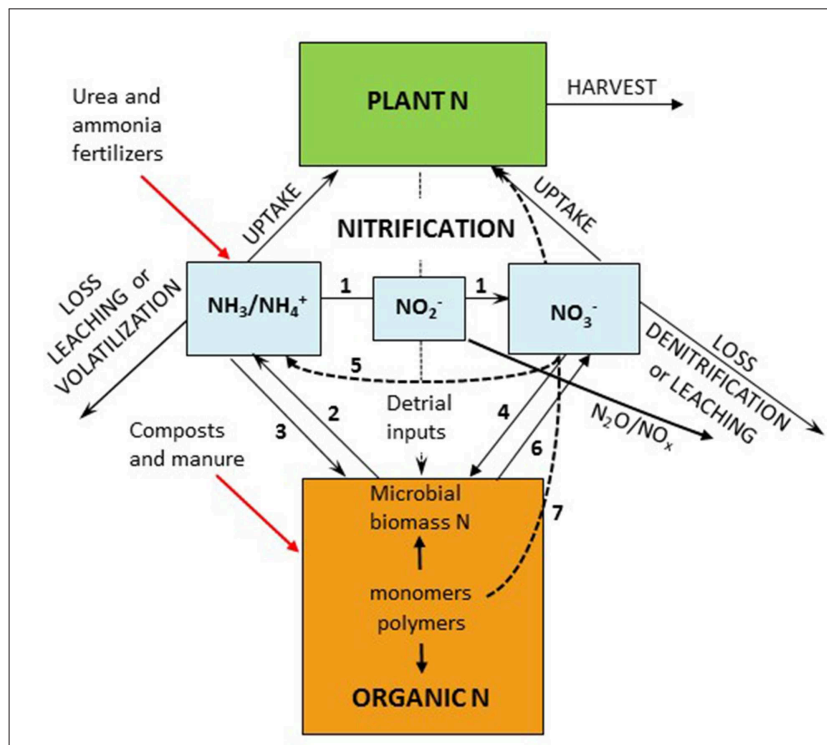

FIGURE 1 | The soil internal nitrogen cycle with (1) nitrification (including comammox), (2) mineralization (ammonification), (3) ammonium immobilization, (4) nitrate immobilization, (5) dissimilatory $\mathrm{NO}_{3}^{-}$reduction to $\mathrm{NH}_{3}$ (DNRA), (6) hetrotrophic nitrification, and (7) plant uptake of monomers. is more likely than $\mathrm{NH}_{4}^{+}$to move rapidly via mass flow to plant roots, leach out of the root zone or be lost from the soil by denitrification. For these reasons, it is often desirable to manage agricultural soils to reduce nitrification, improve the match between available $\mathrm{N}$ supply and plant demand and increase $\mathrm{N}$ fertilizer use efficiency.

In classical autotrophic nitrification, the conversion of $\mathrm{N}$ takes place in two steps: in the ammonia oxidizing bacteria (AOB) such as Nitrosomonas or Nitrosospira, $\mathrm{NH}_{4}^{+}$is converted to hydroxylamine and then to $\mathrm{NO}_{2}^{-}$with a net outcome shown in Equation 1. Ammonia oxidizing archaea (AOA) such as Nitrososphaera have been shown to oxidize $\mathrm{NH}_{4}^{+}$to $\mathrm{NO}_{2}^{-}$ (Schleper and Nicol, 2010) although by a significantly distinct metabolism from the AOB (Kozlowski et al., 2016).

$$
\mathrm{NH}_{4}^{+}+1.5 \mathrm{O}_{2} \rightarrow \mathrm{NO}_{2}^{-}+\mathrm{H}_{2} \mathrm{O}+2 \mathrm{H}^{+}
$$

While the nitrite oxidizing bacteria (NOB) such as Nitrobacter or Nitrospira convert $\mathrm{NO}_{2}^{-}$to $\mathrm{NO}_{3}^{-}$

$$
\mathrm{NO}_{2}^{-}+0.5 \mathrm{O}_{2} \rightarrow \mathrm{NO}_{3}^{-}
$$

Recently certain Nitrospira bacteria have been found that mediate the entire reaction from $\mathrm{NH}_{4}^{+}$to $\mathrm{NO}_{3}^{-}$within one organism in the Complete Ammonia Oxidation to nitrate known as Comammox (Daims et al., 2015; van Kessel et al., 2015).

$$
\mathrm{NH}_{4}^{+}+2 \mathrm{O}_{2} \rightarrow \mathrm{NO}_{3}^{-}+\mathrm{H}_{2} \mathrm{O}+2 \mathrm{H}^{+}
$$

Many AOB, AOA, NOB, and Comammox organisms gain energy from these reactions and then grow by the fixation of inorganic $\mathrm{C}$ into biomass and are therefore chemolithoautotrophs. While it is convenient to group and discuss organisms by the reactions that they mediate, our recent insights into the complexity and versatility of microbial metabolic modules catalyzing $\mathrm{N}$ transformations reminds us that this operational approach is not a static classification (Kuypers et al., 2018), the capability of organisms in their environment is the result of complex genetic potential shaped through their environmental and evolutionary past.

Chemolithotrophic bacteria and archaea that are energetically dependent on oxidizing $\mathrm{NH}_{4}^{+} / \mathrm{NH}_{3}$ and/or $\mathrm{NO}_{2}^{-}$for their growth mediate the majority of nitrification in agricultural soils. For this reason the rate and extent of the nitrification process is closely linked to the abundance and functional ecotypes of these responsible organisms. Simulation modeling of nitrification processes may be improved by inclusion of microbial community or functional gene abundance data into predictive models (Bouskill et al., 2012; Graham et al., 2016; Le Roux et al., 2016; Breuillin-Sessoms et al., 2017). This review covers the main factors controlling nitrification rates in agricultural soils, agricultural practices that may reduce nitrification and associated fertilizer $\mathrm{N}$ loss and the potential interactions of nitrification rates and extent with climate change under agricultural management. 


\section{CONTROLS ON NITRIFICATION IN AGRICULTURAL SOILS}

The main factors controlling the rates of nitrification in agricultural soils include the substrate supply, environmental conditions, organismal populations of nitrifiers and competitors, and the presence of nitrification inhibitors. These factors include those that act directly at the cell level and many that act indirectly affecting the soil habitat of the nitrifying organisms. The timescale for these factors spans from immediate change in rates at minutes to hours spanning to years and decades for changes in the soil organic matter pools and their turnover. There are significant interactions and feedbacks between controlling factors since the populations of active nitrifying microbes is determined by the substrates driving their metabolism and growth. Several mechanistic models simulate nitrification at various levels of complexity and these are compared for their treatment of some of these main controlling factors in Table $\mathbf{1}$.

\section{Substrate Supply Effects on Nitrification}

The substrate supply for energy yielding reactions (Equations 1-3) are important factors controlling nitrification in agricultural soils. The availability of ammonia/ammonium $\left(\mathrm{NH}_{4}^{+} / \mathrm{NH}_{3}\right), \mathrm{NO}_{2}^{-}$, and $\mathrm{O}_{2}$ often limits both the rate of nitrification and the size of the resultant nitrifier populations (Grant, 1994; Bouskill et al., 2012; Nowka et al., 2015; Venterea et al., 2015; Ouyang et al., 2018). Although $\mathrm{O}_{2}$ is an important substrate for nitrification; its availability is closely linked to soil water status and thus $\mathrm{O}_{2}$ availability will be discussed with environmental factors below. In agricultural soil environments, the substrate pool of $\mathrm{NH}_{4}^{+} / \mathrm{NH}_{3}$ is increased by (1) additions of urea and ammonical fertilizers, (2) deposition of animal wastes (urine and feces), (3) atmospheric deposition of $\mathrm{NH}_{4}^{+}$, (4) biological $\mathrm{N}$ fixation, and (5) $\mathrm{NH}_{4}^{+}$production via mineralization. The competing consumptive processes including microbial assimilation (immobilization), plant assimilation, and ammonia volatilization decrease available $\mathrm{NH}_{4}^{+} / \mathrm{NH}_{3}$ (Figure 1).

Nitrification rates are often modeled as first-order with respect to $\mathrm{NH}_{4}^{+} / \mathrm{NH}_{3}$ pools (appropriate for lower concentrations) or using Michaelis-Menten equations (Norton and Stark, 2011; Bouskill et al., 2012; Inselsbacher et al., 2013; Breuillin-Sessoms et al., 2017). Often ammonia oxidation rates are assumed to limit the overall rate of nitrification and nitrite does not accumulate. Some important exceptions are described below. The

TABLE 1 | Simulation models including nitrification rate and their treatment of controlling factors.

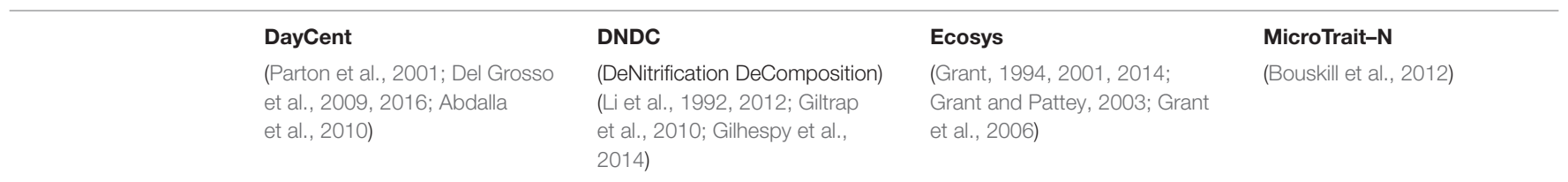

\section{PARAMETER}

Nitrification rate

Nitrification rate is a function of $\mathrm{NH}_{4}^{+}$, water content, temperature, $\mathrm{pH}$, and texture

Soil
ammonia/ammonium
Mineralization
Nitrite
Oxygen in soil

Temperature

Water

Nitrifier abundance

Nitrifier denitrification ( $\mathrm{N} \quad$ Fraction of $\mathrm{N}$ nitrified gas from nitrification)
Model derived soil ammonium

$\times$ maximum fraction nitrified

Net mineralization fraction (.20)

Not modeled

Limited at high WFPS, soil physical properties control gas diffusivity and $\mathrm{O}_{2}$ demand

Ts estimated based on heat flux and soil heat capacity, used as $\mathrm{T}$ factor

Optimum WFPS about 55\% if low scales down nitrification from moisture stress, high scaled down by DOC

Not modeled Fraction of N nitrified

\section{rate is a first order function of} $\mathrm{NH}_{4}^{+}$concentration, nitrifier biomass, a temperature reduction factor, and a moisture reduction factor

$\mathrm{NH}_{4}^{+}$concentration used in Michaelis-Menten kinetics

Submodel of decomposition Not modeled

\section{DOC}

Anaerobic balloon concept

Ts estimated based on heat flux and heat flow used as a $T$ factor compared to optimum

Soil moisture content converted to WFPS, Moisture reduction factor, optimum at $90 \%$ WFPS

Nitrifier biomass, Nitrifier-bacterial growth and death rate are functions of DOC and a $T$ factor.

Function of water-filled pore space and quantity of $\mathrm{N}$ nitrified substrate $\left(\mathrm{NH}_{3}\right)$ oxidation under non-limiting $\mathrm{O}_{2}$ is calculated from active biomass and from $\mathrm{NH}_{3}$ and $\mathrm{CO}_{2}$ concentrations (same for $\mathrm{NO}_{2}^{-}$) Solution $\mathrm{NH}_{4}^{+} / \mathrm{NH}_{3}$ drives rates

Submodel of decomposition Modeled explicitedly Consumption by microbial groups, $\mathrm{O}_{2}$ uptake in competition with heterotrophs, roots; then diffusion to nitrifier

Uses modeled $T_{S}$ applied through Arrhenius function

Water film thickness from modeled water potential

(Active) Nitrifier biomass growth by double Monod functions of $\mathrm{CO}_{2} \mathrm{~s}$ and $\mathrm{NH}_{3} \mathrm{~S}$ $\mathrm{AO}$ and $\mathrm{NO}$ separately

Process included when $\mathrm{O}_{2}$ limits rate of $\mathrm{NH}_{3}$ oxidation
Briggs Haldane kinetics for ammonia and oxygen for $\mathrm{AO}$ and for nitrite and oxygen for $\mathrm{NO}$

Dynamic solution $\mathrm{NH}_{3}$ driven by $\mathrm{pH}$ and consumption

Inputs but not linked Product of $\mathrm{AO}$

$\mathrm{O}_{2}$ use by nitrification reactions

Different temperature optima across guilds Optimum set to $25^{\circ} \mathrm{C}$ Assumed in water films

Growth and death of biomass through $\mathrm{C}$ and $\mathrm{N}$ equations

Decomposition of hydroxylamine or detoxification of $\mathrm{NO}_{2}^{-}$due to uncoupling

AO, ammonia oxidation; NO, nitrite oxidation; T, temperature; s, soil; WFPS, water filled pore space; DOC, dissolved oxygen concentration. 
substrate for the crucial integral membrane protein ammonia monooxygenase (AMO) is generally accepted as solution $\mathrm{NH}_{3}$ (Suzuki et al., 1974). All known substrates and competitive inhibitors of AMO are non-polar (Suzuki et al., 1974; Hooper et al., 1997; Arp et al., 2002) suggesting that the AMO active site is a non-polar environment. Rapid equilibration in aqueous environments means this solution $\mathrm{NH}_{3}$ form is transient and seldom directly measured in soil environments. The determination of solution $\mathrm{NH}_{4}^{+} / \mathrm{NH}_{3}$ in soils is complicated by the microsite variability in $\mathrm{pH}$ and the sorption capacity of the soil (Venterea et al., 2015). These relationships are of particular importance after fertilization or urine deposition resulting in localized high concentrations of substrates. Many but not all AOB and AOA are capable of using urea and have genes encoding urease enzymes and urea transporters (De Boer and Laanbroek, 1989; Burton and Prosser, 2001; Koper et al., 2004; Tourna et al., 2011; Lu and Jia, 2013; Shen et al., 2013). Some comammox organisms and NOB also possess ureolytic activity (Koch et al., 2015, 2019; Palomo et al., 2018).

The injection of anhydrous ammonia and banding of urea fertilizers in soils results in temporarily extremely high $\mathrm{NH}_{4}^{+} / \mathrm{NH}_{3}$ concentrations and high $\mathrm{pH}$ as well. In these localized zones total $\mathrm{NH}_{4}^{+} / \mathrm{NH}_{3}$ may reach from several hundred up to 2,000 mg N/kg soil (Venterea et al., 2015). Under these episodic high concentrations, existing populations of ammonia oxidizers are operating at maximum capacity or even inhibited by high substrate $\left(\mathrm{NH}_{3}\right)$ or product $\left(\mathrm{NO}_{2}^{-}\right)$concentrations.

In general, $\mathrm{NO}_{2}^{-}$does not accumulate in soils except under transient conditions that have decreased the population or inhibited the activity of nitrite oxidizers. The intensive application of ammonical fertilizers (i.e., urea or anhydrous $\mathrm{NH}_{3}$ ) may result in $\mathrm{NO}_{2}^{-}$accumulation due to the inhibition of $\mathrm{NO}_{2}^{-}$ oxidation from the toxicity of high $\mathrm{NH}_{3}$ levels in the application zone (Schmidt, 1982; Maharjan and Venterea, 2013; Giguere et al., 2017) or from subsequent localized lowering of $\mathrm{pH}$ and production of nitrous acid (Venterea and Rolston, 2000a). Any circumstance under which the rate of $\mathrm{NH}_{3}$ oxidation exceeds that of $\mathrm{NO}_{2}^{-}$oxidation will result in accumulation. This accumulation of $\mathrm{NO}_{2}^{-}$is an important driver of $\mathrm{N}_{2} \mathrm{O} / \mathrm{NO}_{\mathrm{x}}$ production by both biological and abiotic reactions (Venterea et al., 2015; Heil et al., 2016; Breuillin-Sessoms et al., 2017; Giguere et al., 2017). The interaction of soil $\mathrm{pH}$, buffering capacity and ionization of $\mathrm{NH}_{3}$ and $\mathrm{NO}_{2}^{-}$may be useful predictors of $\mathrm{NO}_{2}^{-}$accumulation and the associated increased production of $\mathrm{N}_{2} \mathrm{O} / \mathrm{NO}_{\mathrm{x}}$ via nitrification and nitrifier-denitrification (Venterea and Rolston, 2000b).

The deposition or application of animal wastes due to grazing or amendments leads to local zones of high organic $\mathrm{N}$, urea and $\mathrm{NH}_{4}^{+} / \mathrm{NH}_{3}$. Typically, over $70 \%$ of the $\mathrm{N}$ in ruminant urine is found as urea and localized deposition zones reach $\mathrm{NH}_{4}^{+} / \mathrm{NH}_{3}$ concentrations and elevated $\mathrm{pH}$ similar to those found in urea fertilizer bands. For intensively grazed pastures levels of deposition may reach up to $600-1,200 \mathrm{~kg} \mathrm{~N}^{-1}$ significantly exceeding uptake by pasture plants (Hamonts et al., 2013). Applications of manures and composts to agricultural lands adds urea, organic $\mathrm{N}$ and $\mathrm{NH}_{4}^{+} / \mathrm{NH}_{3}$ often stimulating nitrification rates in the receiving soils (Li et al., 2012).

Rates of $\mathrm{NH}_{3}$ emissions are increasing with agricultural activities accounting for $80-90 \%$ of anthropogenic emissions.
Increasing manure production and $\mathrm{N}$ fertilizer use drives $\mathrm{NH}_{3}$ emissions and then subsequent deposition to land surfaces both globally and locally. Total $\mathrm{N}$ in wet and dry deposition approximately tripled during the last century (Simkin et al., 2016). Deposition typically occurs at a sustained elevated level in contrast to the large pulses of $\mathrm{NH}_{4}^{+} / \mathrm{NH}_{3}$ due to fertilization. These increased inputs can be expected to affect soil inorganic $\mathrm{N}$ pools for surface soils, most importantly in low fertility ecosystems.

Rates of $\mathrm{NH}_{4}^{+} / \mathrm{NH}_{3}$ production and consumption are important controls on the rate and extent of nitrification (Norton, 2008; Grant et al., 2016). Mineralization is the general term for the conversion of organic $\mathrm{N}$ to inorganic $\mathrm{N}$ as either $\mathrm{NH}_{4}^{+}$or further to $\mathrm{NO}_{2}^{-} / \mathrm{NO}_{3}^{-}$, ammonification is the conversion of organic $\mathrm{N}$ to the $\mathrm{NH}_{4}^{+}$form while immobilization is the assimilation of inorganic $\mathrm{N}$ to organic $\mathrm{N}$ generally mediated by microorganisms. Mineralization-immobilization turnover (MIT) refers to the combined transformations between organic and inorganic $\mathrm{N}$ that accompanies the growth and death of the soil biota. The supply of $\mathrm{NH}_{4}^{+}$for nitrification depends upon the balance of mineralization to immobilization and the quality and quantity of substrate for decomposition. Soil organic C and $\mathrm{N}$ pool size are effective predictors of soil mineralization rates when considered over continental scales (Booth et al., 2005). In tightly coupled $\mathrm{N}$ cycles the pool size of $\mathrm{NH}_{4}^{+}$does not reflect the supply of this substrate. Plant uptake may compete directly for $\mathrm{NH}_{4}^{+}$. Assessment of the true inorganic $\mathrm{N}$ supplying capacity of the soil, i.e., gross ammonification, may better represent the absolute flux of inorganic $\mathrm{N}$ produced by soil $\mathrm{N}$ mineralization (Van Groenigen et al., 2015). The fraction of the mineralized $\mathrm{N}$ that is nitrified or the ratio of gross nitrification to mineralization (GNR/GMR) (Table 2) is considered an index of the nitrifying capacity of soils (Booth et al., 2005; Habteselassie et al., 2006). Nitrification potentials that measure short-term nitrite/nitrate production in shaken soil slurries with non-limiting substrate supply, are useful indicators of the enzymatic potential for nitrification but are not necessarily predictive of in-situ rates (Hart et al., 1994; Norton and Stark, 2011). Soils that have received repeated applications of composts and manures typically show increases in the ratio of gross nitrification rate to nitrification potential (GNR/NP) because high rates of mineralization continuously supply substrate $\mathrm{NH}_{4}^{+}$ (Table 2) (Habteselassie et al., 2006; Ouyang et al., 2016). Relationships of mineralization to nitrification rates are best assessed through the determination of gross rates using isotope pool dilution and modeling approaches. These comparisons of gross and net nitrification rates are evidence that net nitrification measurements are poor predictors of gross nitrification rates for many soils (Stark and Hart, 1997; Burger and Jackson, 2003, 2004; Habteselassie et al., 2006; Norton and Stark, 2011; Han et al., 2012).

\section{Environmental Conditions-Temperature, Soil Moisture, Aeration, and pH Temperature}

The response of nitrification to temperature has been evaluated in a diverse range of soils, and the optimum temperature for 
TABLE 2 | Ratios of gross and net N transformation rates for an agricultural soil under silage corn that received ammonium sulfate (AS), dairy waste compost (DC), and dairy liquid waste (LW) at 100 and $200 \mathrm{~kg}$ available $\mathrm{N} \mathrm{ha}^{-1}$ for 6 years.

\begin{tabular}{llll}
\hline Treatment & NNR $^{\mathrm{a}} /$ GNR & GNR/GMR & GNR/NP \\
\hline AS100 & $0.38^{\mathrm{ba}}$ & $0.59^{\mathrm{b}}$ & $0.10^{\mathrm{b}}$ \\
AS200 & $0.36^{\mathrm{ba}}$ & $0.66^{\mathrm{b}}$ & $0.09^{\mathrm{b}}$ \\
DC100 & $0.16^{\mathrm{b}}$ & $1.36^{\mathrm{ab}}$ & $0.58^{\mathrm{a}}$ \\
DC200 & $0.15^{\mathrm{b}}$ & $1.88^{\mathrm{a}}$ & $0.64^{\mathrm{a}}$ \\
LW100 & $0.46^{\mathrm{ab}}$ & $0.78^{\mathrm{ba}}$ & $0.18^{\mathrm{b}}$ \\
LW200 & $0.69^{\mathrm{a}}$ & $0.66^{\mathrm{b}}$ & $0.22 \mathrm{~b}^{\mathrm{a}}$
\end{tabular}

GNR/GMR, and GNR/NP values are means for year 1999 to 2002 (Habteselassie et al., 2006). Numbers followed by same letter within a column are not significantly different at $P<0.05$.

${ }^{a}$ From laboratory incubation measurements.

NNR, net nitrification rate; GNR, gross nitrification rate; GMR, gross mineralization rate; NP, nitrification potential.

nitrification has been found to be environment specific (Stark, 1996; Parton et al., 2001; Lu et al., 2018). Across a range of North American ecosystems, the community composition of $\mathrm{AOB}$ was correlated with temperature as indicated by mean annual temperature (Fierer et al., 2009). The temperature optimum for nitrification in an AOA dominated soil has also been found to be increased under selective warming pressure and to have selected for temperature optima related to the environment (Daebeler et al., 2017). Overall soil microbial communities tend to be temperature generalists since they are adapted to wide swings of temperature in surface soil habitats (Wallenstein and Hall, 2012). Generally, the optimum temperature for maximum short-term nitrification rates (i.e., $\mathrm{V}_{\text {max }}$ ) may exceed the temperatures normally experienced at the site under consideration and may exceed the temperature optimum for growth of nitrifier biomass (Stark and Firestone, 1996; Taylor et al., 2017). Cultured AOB from soils generally have temperature optimum between 25 and $30^{\circ} \mathrm{C}$ (Jiang and Bakken, 1999), but N. cryotolerans from the Arctic Ocean has a temperature optimum for growth of $22^{\circ} \mathrm{C}$ and can grow at $0^{\circ} \mathrm{C}$ (Koops et al., 1991). There is evidence for soil nitrifier activity under similarly cold temperatures typical of winter season soils $\left(2-10^{\circ} \mathrm{C}\right)$ (Cookson et al., 2002) and for nitrification in AOA dominated Artic soils (Alves et al., 2013). Recent evidence suggests that certain groups of acid tolerant AOA may also be adapted to lower temperatures regimes (GubryRangin et al., 2017). The temperature response of nitrification has been modeled using the Arrhenius equation (Grant, 1994), a Poisson density function (Stark, 1996; Ouyang et al., 2017), square root (SQRT) function or using macromolecular rate theory (MMRT) (Taylor et al., 2017). Studies performed with pure cultures and with mixed environmental consortia from temperate agricultural soils consistently indicate that AOA activity has a higher temperature optima and higher temperature minimum than $\mathrm{AOB}$ activity (Figure 2) (Ouyang et al., 2017; Taylor et al., 2017; Lu et al., 2018). Modeled temperature response parameters may be useful for trait based modeling linking microbial populations to nitrification rates (Bouskill et al., 2012; Breuillin-Sessoms et al., 2017).

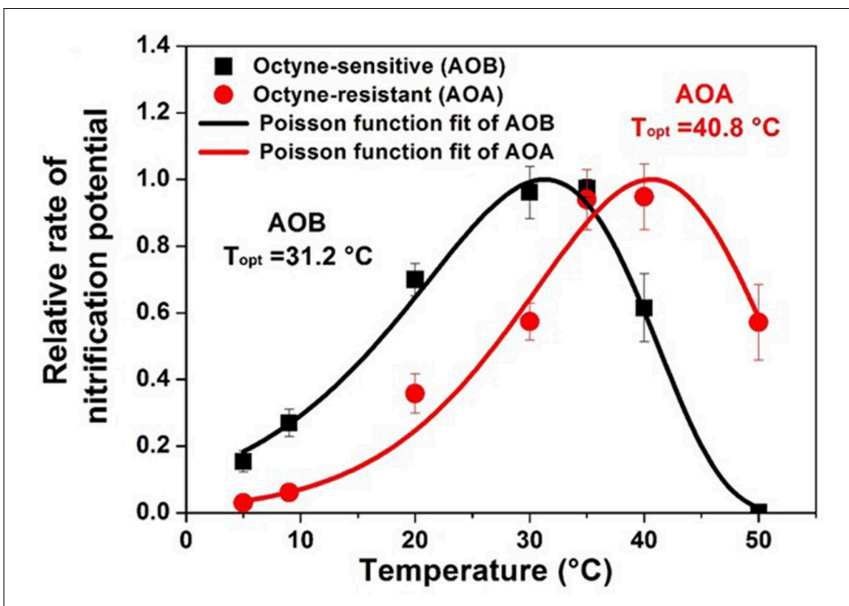

FIGURE 2 | Temperature response of the relative potential nitrification rates for AOB (octyne-sensitive) and AOA (octyne-resistant) from a calcareous agricultural soil in Utah, USA. Rates are normalized to the fraction of maximum nitrification potentials at optimum temperature. Lines predicted by generalized Poisson density equation (Adapted from Ouyang et al., 2017).

\section{Moisture/Aeration}

Soil moisture affects nitrification rates through several confounding influences of substrate availability of both ammonium and oxygen by diffusion and direct effects of dehydration at very low water potentials. These interdependent factors often confound experiments to determine the role of soil drying and wetting on nitrification rates under field conditions (Stark and Firestone, 1995; Placella and Firestone, 2013). Optimum water filled pore space (WFPS) for nitrification is around 55\% for fine textured soils and around $40 \%$ WFPS for coarse textured soils (Parton et al., 2001) see Supplemental Figure 1). Nitrification in soils saturated with water (i.e., water potential approaching $0 \mathrm{kPa}$ ) is inhibited due to lack of available oxygen. Nitrification nearly halts in very dry soils $(<-3.0 \mathrm{MPa})$, such as found under seasonal dry xeric or aridic soil climates. In general, the diffusion of substrates limits nitrification activity most near optimum water potentials, whereas the adverse physiologic effects associated with cell dehydration will be the most limiting factor at very low water potentials (Stark and Firestone, 1995). In the nitrification submodel of DayCent (Del Grosso et al., 2012) nitrification is limited by moisture stress when soil water-filled pore space (WFPS) is too low and by $\mathrm{O}_{2}$ availability when WFPS is high based on soil textural class (Supplemental Figure 1). In the highly detailed model Ecosys, $\mathrm{O}_{2}$ availability is based on water film thickness and the wide range of competing microbial processes consuming $\mathrm{O}_{2}$ (Grant and Pattey, 2003).

\section{Soil pH}

The soil $\mathrm{pH}$ is one of the most important factors controlling rates and product accumulation from nitrification see Supplemental Figure 1 (Parton et al., 2001; Kyveryga et al., 2004). Rates of both ammonia and nitrite oxidation are generally favored by neutral to slightly alkaline soils and it is in these soils that the largest losses or accumulations of $\mathrm{NO}_{3}^{-}$generally 
occur. Management of agricultural soil $\mathrm{pH}$ by liming is common practice in vast areas of crop production and is often necessary to offset acidification due to fertilizers. Currently $\sim 40 \%$ of the world's arable soils are acidic and this area has recently been increasing (Kunhikrishnan et al., 2016). High rates of nitrification and leaching of $\mathrm{NO}_{3}^{-}$further acidify agricultural soils (Schroder et al., 2011). During the Twentieth century, observations that nitrification was occurring in acids soils from both natural and agricultural ecosystems continued to accumulate with observations from tea plantations, heath soils and coniferous forests (De Boer and Kowalchuk, 2001). During this same time frame the available isolates of $\mathrm{AOB}$ were fairly intolerant of acidity and their nitrification rates decreased dramatically as pH decreased (De Boer and Kowalchuk, 2001). These observations were partially explained by the known low concentrations of $\mathrm{NH}_{3}\left(\mathrm{NH}_{4}^{+} / \mathrm{NH}_{3}\right.$ couple has a $\mathrm{pK}$ and the contention that $\mathrm{NH}_{3}$ is the actual substrate for ammonia oxidizers (Suzuki et al., 1974). The use of urea as a substrate, microsite variability of soil $\mathrm{pH}$ and heterotrophic nitrification were able to explain some portion of nitrification observed in acid soils (Burton and Prosser, 2001). Since the role of AOA in ammonia oxidation in the soil environment was revealed (Treusch et al., 2005; Leininger et al., 2006; Nicol et al., 2008) the importance of AOA in the ammonia oxidation of acid soils has gained increasing support (Nicol et al., 2008; Gubry-Rangin et al., 2010; Yao et al., 2011, 2013; Prosser and Nicol, 2012; Li et al., 2018). Members of the AOA Nitrosotalea lineage are abundant and widely distributed in acidic soils globally (Gubry-Rangin et al., 2011). An obligate acidophilic isolate, Ca. Nitrosotalea devanaterra, is unable to grow at neutral $\mathrm{pH}$ (Lehtovirta-Morley et al., 2011) and exhibits specialized genomic inventory for functioning under acid conditions (Lehtovirta-Morley et al., 2016b). Soil pH has also been observed to affect the nitrite oxidizer community (Han et al., 2017).

\section{Effects of Abundance and Community Structure of Nitrifiers on Rates}

There is a complex interaction between the soil environment, plant community and management (especially fertilization) that determines the community structure of nitrifiers in agricultural soils (Bertagnolli et al., 2016; Han et al., 2018). The abundance and ecotypes of the ammonia and nitrite oxidizers present in the soil may control the immediate rate of nitrification especially when substrate is in excess. Generally, when fertilizers are applied the existing populations respond relatively quickly to the transient increased substrate availability dependent upon favorable environmental conditions. Comparisons between the responses of $\mathrm{AOB}$ and $\mathrm{AOA}$ to fertilizers suggest that the kinetics of their responses to substrate are distinct (Prosser and Nicol, 2012). An example from Utah agricultural soil comparing the $\mathrm{AOB}$ and $\mathrm{AOA}$ response shows that $\mathrm{AOA}$ reached a lower Vmax at a much lower substrate availability (Figure 3) (Ouyang et al., 2017). Nitrification driven by AOA was also found to be saturated at relatively low $\mathrm{NH}_{4}^{+}$in a range of Oregon soils (Giguere et al., 2015). These observations explain why some studies have observed a positive correlations between the abundance of $\mathrm{AOB}$ and nitrification potential rates performed at relatively high $\mathrm{NH}_{4}^{+}(1 \mathrm{mM})$ but little or no correlation with potential rates and AOA abundances (Jia and Conrad, 2009; Taylor et al., 2012; Ouyang et al., 2016). In contrast to these

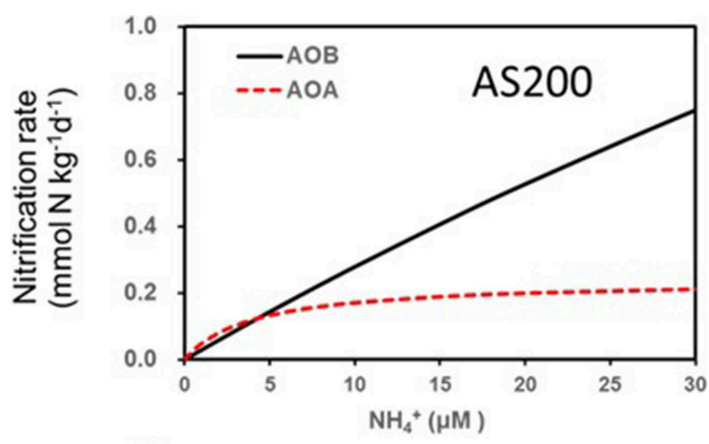

$$
\begin{aligned}
& \mathrm{V}=\mathrm{V}_{\max } * \mathrm{~S} /\left(\mathrm{K}_{\mathrm{m}}+\mathrm{S}\right) \\
& \text { AOB: } V_{\max }=4.8 \mathrm{mmol} \mathrm{N} \mathrm{kg}^{-1} \mathrm{~d}^{-1} \text {; } \\
& \mathrm{k}_{\mathrm{m}}=161 \mu \mathrm{M} \\
& \text { AOA: } V_{\max }=0.3 \mathrm{mmol} \mathrm{N} \mathrm{kg}^{-1} \mathrm{~d}^{-1} \text {; } \\
& k_{m}=3.6 \mu \mathrm{M}
\end{aligned}
$$

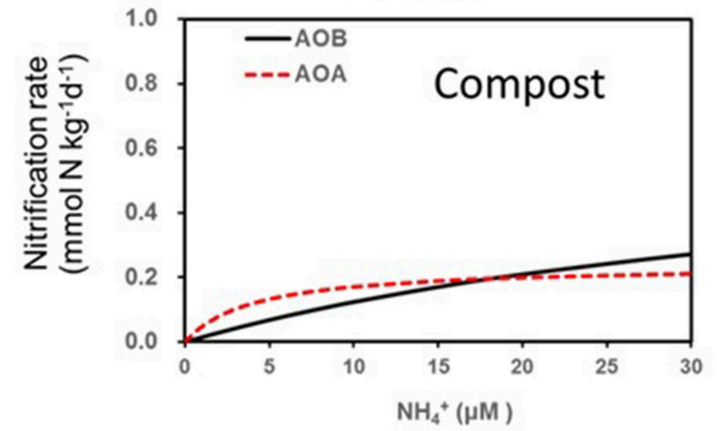

AOB: $V_{\max }=0.7 \mathrm{mmol} \mathrm{N} \mathrm{kg}^{-1} \mathrm{~d}^{-1}$; $k_{m}=44 \mu \mathrm{M}$

AOA: $V_{\max }=0.2 \mathrm{mmol} \mathrm{N} \mathrm{kg}^{-1} \mathrm{~d}^{-1}$; $\mathrm{k}_{\mathrm{m}}=2.9 \mu \mathrm{M}$

These are apparent kinetic constants

FIGURE 3 | Nitrification rate kinetic models based on substrate concentrations for a calcareous agricultural soil from Utah treated for 3 years with either ammonium sulfate or steer waste compost at $200 \mathrm{~kg} \mathrm{~N} / \mathrm{ha}$. Soils were sampled 28 days after fertilization (adapted from Ouyang et al., 2017). 
observations, under conditions such as acid soils that favor AOA, nitrification rate is often proportional to AOA gene abundance (Yao et al., 2011). In Scotland, a survey that included nitrification potentials, $\mathrm{AOB}$ and $\mathrm{AOA}$ abundances and their communities found that specific phylotypes of $\mathrm{AOA}$ and $\mathrm{AOB}$ were linked to soil niches described by combinations of soil $\mathrm{pH}$ and fertilization (Yao et al., 2013). In general, acidic soils from nonfertilized systems exhibited lower rates and were dominated by distinctive AOA phylotypes. In calcareous agricultural soils from Utah, nitrification potentials (at $1 \mathrm{mM} \mathrm{NH}_{4}^{+}$) were dominated by activity of $\mathrm{AOB}$ related to Nitrosospira even though the AOA were more abundant. However, in these same soils, net and gross nitrification rates were mediated by $\mathrm{AOB}$ in the first weeks following fertilization then, after ammonium was depleted, the activity was dominated by AOA Figure 4 (Ouyang et al., 2017). Candidatus Nitrosocosmicus franklandus is an AOA strain (Archaea, Thaumarchaeota, Nitrososphaerales) isolated from circum-neutral $\mathrm{pH}$, fertilized soil in Scotland (LehtovirtaMorley et al., 2016a) has an overlapping ammonia tolerance to known $\mathrm{AOB}$ soil isolates. In the acidic red soils of China after 16 years of contrasting fertilizer treatments (He et al., 2007), the AOA remained dominant but both AOA and AOB abundances were increased by organic and inorganic fertilizers, both $\mathrm{AOA}$ and $\mathrm{AOB}$ played a role in nitrification activity. The abundance of AOA and AOB has been suggested as a bioindicator for soil monitoring based on their differential responses to soil management and relative ease of quantification by real-time PCR (Wessen et al., 2010; Wessén and Hallin, 2011).

Enrichment and pure culture studies of the AOB suggest that substrate kinetics and growth response of $\mathrm{AOB}$ differ even within a genus (Jiang and Bakken, 1999; Koops and PommereningRoser, 2001; Bollmann et al., 2002; Webster et al., 2005; Bouskill et al., 2012; Sedlacek et al., 2019). Different ecophysiology within the AOA is also indicated by pure culture work (Gubry-Rangin et al., 2011; Martens-Habbena and Stahl, 2011; Hatzenpichler, 2012; Kits et al., 2017).

Fewer assessments have been made of the NOB communities of agricultural soils. Several studies suggest nitrite oxidation in agricultural soils is primarily catalyzed by NOB communities with members from Nitrospira and Nitrobacter (Freitag et al., 2005; Xia et al., 2011; Pester et al., 2014). Higher potential rates of nitrite oxidation have been found to be associated with Nitrobacter vs. Nitrospira dominated communities and shifts toward Nitrobacter types are often associated with changes in management such as nitrogen fertilization and tillage (Attard et al., 2010; Le Roux et al., 2016; Han et al., 2018). The growth of Nitrobacter populations as indicated by nxrA gene copies has been associated with rapid nitrite use and lowered $\mathrm{N}_{2} \mathrm{O}$ emissions (Venterea et al., 2015). Nitrobacter vulgaris was also found to quickly decrease accumulated nitrite and prevent $\mathrm{N}_{2} \mathrm{O}$ emissions in several Oregon soils (Giguere et al., 2017). Pure cultures of Nitrospira spp. generally exhibit higher affinities and lower Vmax than Nitrobacter spp. (Nowka et al., 2015). Kinetics of the comammox bacterium, Nitrospira inopinata, suggest an oligotrophic lifestyle as well (Kits et al., 2017).

Feedback between fertilizer application and abundance occurs because both the activity and the abundance of nitrifying

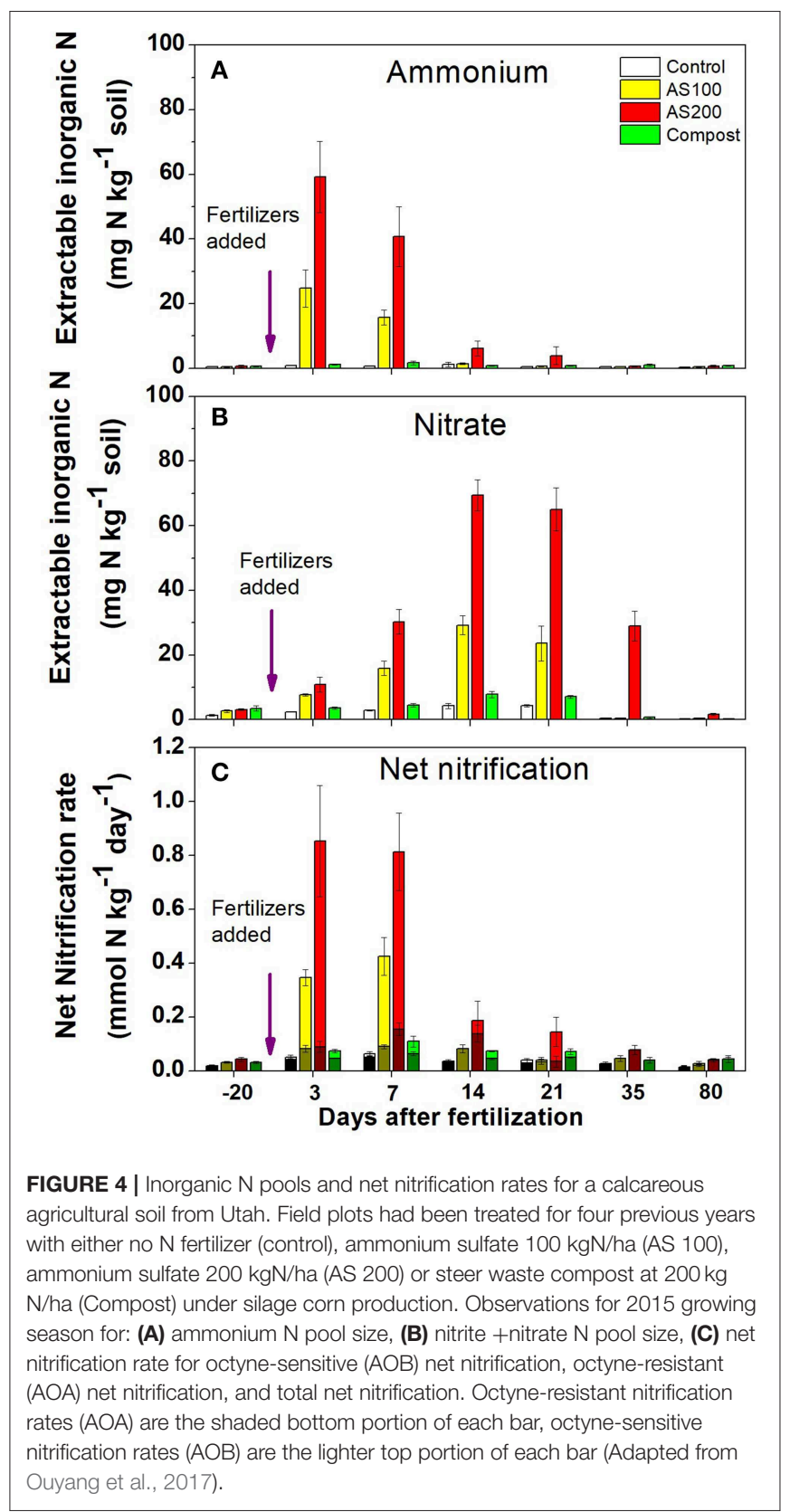

organisms increase following fertilization with ammonical $\mathrm{N}$ fertilizers (He et al., 2007; Ouyang et al., 2016, 2018; Xiang et al., 2017; Orellana et al., 2018). A recent meta-analysis examined the impact of $\mathrm{N}$ fertilization on the abundance of $\mathrm{N}$ cycling genes in agricultural soils showed that the positive effect size was significant for both the AOA and AOB from a survey of $\sim 100$ samples each (Ouyang et al., 2018). In an earlier metaanalysis (Carey et al., 2016) the AOB abundance was found to be more responsive to $\mathrm{N}$ fertilization than that of $\mathrm{AOA}$ for the majority of observations. AOB abundance was associated with increased nitrification potentials in fertilized soils. In Utah soils, both the abundance and the community of ammonia AOB 
were more responsive than those of AOA to repeated annual applications of ammonium sulfate fertilizer (Ouyang et al., 2016). Generally, nitrification potential activities were more sensitive to agricultural management practices and environment disturbance than to the abundance and diversity of nitrifiers. For example, in our Utah soil, nitrification potentials were significantly increased by $\mathrm{N}$ fertilizers after the first fertilization, while amoA gene abundance and diversity showed no significant difference among treatments (Ouyang et al., 2016). Similarly, we found that the nitrite oxidation potentials were significantly stimulated by fertilizers while $n x r B$ abundances were not affected (Ouyang, 2016). These amo $A$ and $n x r B$ gene measurement were based on soil DNA, while the rate of ammonia oxidation may be more related to the relationship among transcription, translation, and enzyme function (Nicol et al., 2008; Myrold et al., 2014; Rocca et al., 2015).

Regulation of transcription of nitrification related genes has been examined both in pure cultures (Sayavedra-Soto et al., 1998, 2015; Bollmann et al., 2005; Hawkins et al., 2007; Starkenburg et al., 2008; Park and Ely, 2009; Radniecki and Lauchnor, 2011), and in soil or sediment environments (Tourna et al., 2008; Di et al., 2010; Gubry-Rangin et al., 2010; Abell et al., 2011; Herrmann et al., 2012; Placella and Firestone, 2013) primarily targeting amo $A$ transcription. In a meta-analysis of functional genes and transcript abundance and their relationship to process rates (Rocca et al., 2015) there was less correlation between transcript level (mRNA) and process rates than with gene abundance and process rate. This lack of relationship between transcription and process rate is not surprising considering differences in transcript stability (turnover), transient and episodic rates of transcription and subsequent translation and difficulties with methods for determining transcript abundance in environmental matrices.

A proteomic approach might be appropriate for explaining short-term changes in nitrification activity. The ideal method is to extract and purify key enzymes such as AMO and NXR directly for assays in soils, but the membrane-bound feature of these enzymes makes this strategy difficult (Arp et al., 2002; Kerou et al., 2016). However, the recent study on activity-based protein profiling of AMO in Nitrosomonas europaea may pave a way to indirectly quantifying active AMO fluorescently in soils (Bennett et al., 2016). Nitrification is likely the soil $\mathrm{N}$ cycle process for which we are approaching a level of understanding when we may include some nitrifier community characteristics into process models using trait-based modeling approaches (Bouskill et al., 2012; Le Roux et al., 2016).

\section{Plant and Microbial Interaction With Nitrifiers}

Plants take up and assimilate both $\mathrm{NH}_{4}^{+}$and $\mathrm{NO}_{3}^{-}$, but often shows substantial differences in preference for one inorganic $\mathrm{N}$ form (Marschner, 2011). This $\mathrm{NH}_{4}^{+}$or $\mathrm{NO}_{3}^{-}$preference of plant species could exert differential effects on nitrifiers (Patra et al., 2006; Skiba et al., 2011; Thion et al., 2016). Plant often stimulates soil $\mathrm{N}$ transformation processes by releasing $\mathrm{C}$ into the rhizosphere either as root exudates or as direct transfers to mycorrhizal fungi (Phillips et al., 2011; Shi et al., 2016; Meier et al., 2017). A meta-analysis summarized that $\mathrm{N}$ transformation processes were significant higher in rhizosphere than bulk soil, including net and gross $\mathrm{N}$ mineralization and net nitrification (Finzi et al., 2015). Rhizosphere interactions have been observed to decrease nitrification (net and gross rates) by favoring plant and microbial assimilation of $\mathrm{NH}_{4}^{+}$(Hawkes et al., 2007). Some plants are able to produce nitrification inhibitors in their root exudates, and therefore suppress nitrifier activities (Subbarao et al., 2013, 2015; Coskun et al., 2017). While competition for $\mathrm{N}$ between plants and microbes is very strong in the rhizosphere, it is not clear if nitrifiers will outcompete heterotrophic microbes in the rhizosphere (Kuzyakov and Xu, 2013).

Evidence from pure cultures indicate that Nitrosomonas spp. are weak competitors for $\mathrm{NH}_{4}^{+}$, compared to heterotrophic bacteria (Verhagen and Laanbroek, 1991; Verhagen et al., 1994; Bollmann et al., 2002). In many agricultural soils, gross nitrification rates are often 1-75 fold higher than rates of microbial $\mathrm{NH}_{4}^{+}$assimilation indicating that soil nitrifiers are strong competitors for $\mathrm{NH}_{4}^{+}$(Burger and Jackson, 2003; Booth et al., 2005; Inselsbacher et al., 2010). Heterotrophic microbes may assimilate nitrate as well especially under high organic matter and high $\mathrm{C}$ availability. The balance between organic $\mathrm{C}$ and $\mathrm{NH}_{4}^{+}$availability will likely determine the fate of $\mathrm{NH}_{4}^{+}$during competition in agricultural soils.

Arbuscular mycorrhizal fungi (AMF) may play an important role in mediating availability of $\mathrm{NH}_{4}^{+}$to nitrifiers. AMF could directly compete for $\mathrm{NH}_{4}^{+}$(Veresoglou et al., 2011, 2012; Chen et al., 2013; Storer et al., 2018), but also likely exert indirect influences on nitrifiers via the plant (Chen et al., 2013; Veresoglou et al., 2018). AOA community composition was altered more than the AOB community by AMF (Chen et al., 2013). Ectomycorrhizal fungi produce many extracellular enzymes for $\mathrm{N}$ mineralization and may increase the availability of soil N (Courty et al., 2010). Interestingly, ectomycorrhizal fungi inoculation changed $\mathrm{AOA}$, but not $\mathrm{AOB}$ communities in an acid soil (Li et al., 2019).

The biological interaction between soil microfauna and microorganisms in the soil food web also mediates soil $\mathrm{N}$ cycling (Xiao et al., 2010; Jiang et al., 2014; Trap et al., 2016; Zhu et al., 2018). For example, Xiao et al. (2010) found the presence of bacterivorous nematodes significantly stimulated nitrification activity and changed the community composition of AOB. Interestingly, Zhu et al. (2018) showed bacterivorous nematodes significantly reduced the abundance of AOB, but increased AOA, irrespective of the nematode species in the soil. There may also be a role for bacterial predators such as Micavibrio that have been observed in wastewater systems to prey upon Nitrospira (Dolinšek et al., 2013). The knowledge of potential environmental interactions between viruses and nitrifiers is limited although genomes of AOB have shown evidence of prophage (Chain et al., 2003; Stein et al., 2007; Norton et al., 2008). More recently prophage induction by stress followed by lysis was demonstrated in Nitrosospira multiformis (Choi et al., 2010). The outcome of these complex interactions in agricultural soils is driven by the timing and intensity of organic $\mathrm{C}$ and available $\mathrm{N}$ and their distribution by mass flow and diffusion through the soil fabric. 


\section{MANAGING NITRIFICATION IN AGRICULTURAL SOILS}

Meeting world food demand while reducing surplus $\mathrm{N}$ lost to the environment will require substantial increases in the NUE of agricultural systems (Zhang et al., 2015). Management strategies are needed that minimize the risk of $\mathrm{N}$ loss even in high productivity systems that necessarily require high $\mathrm{N}$ inputs. As the demand for food production increases globally, the production and use of $\mathrm{N}$ fertilizer will likely continue to increase from $\sim 110 \mathrm{Tg} \mathrm{N}$ in 2013 up to $120 \mathrm{Tg}$ by 2018 (FAO, 2015). The vast majority of $\mathrm{N}$ fertilizers applied to soils are in the ammonical forms including urea (57\% in 2013 and increasing) and are therefore subject to nitrification after application. In the United States, $\sim 50 \%$ of this $\mathrm{N}$ fertilizer is used on maize (corn) crops (USDA, ERS, 2018). As agriculture intensifies, there will be higher levels of $\mathrm{N}$ applied to reach the yield potential of the most productive varieties if current conventional management continues. Common principles for $\mathrm{N}$ management include the " $4 \mathrm{Rs}$ " approach of applying the right source, at the right rate, at the right time in the right place (Clarke and Beegle, 2014). Many appropriate technologies are currently available to reduce nitrification, greenhouse gas (GHG) emissions and $\mathrm{N}$ losses but these may require appropriate incentives for farmers to adopt (Robertson et al., 2013). Complex models such as DayCent (Del Grosso et al., 2012) that are used for the estimation of the flux of $\mathrm{N}_{2} \mathrm{O}$ from agricultural soils include nitrification submodels. The outcomes of management activities may be simulated and assessed with these tools.

China has some of the most intensive use of $\mathrm{N}$ fertilizers and associated high levels of $\mathrm{N}$ loss. In a meta-analysis of Chinese agriculture, management practices designed to minimize $\mathrm{N}$ loss were assessed including: the application of controlled-release $\mathrm{N}$ fertilizers, nitrification inhibitors (NI) and urease inhibitors (UI), higher splitting frequency of fertilizer $\mathrm{N}$ application, lower basal $\mathrm{N}$ fertilizer (BF) proportion, deep placement of $\mathrm{N}$ fertilizer, and optimizing $\mathrm{N}$ rate based on soil $\mathrm{N}$ test (Xia et al., 2017). These knowledge-based $\mathrm{N}$ fertilization practices were generally effective at reducing $\mathrm{N}$ loss by leaching, runoff and GHG emission while showing some increases in economic return. Split applications of $\mathrm{N}$ and the use of enhanced efficiency fertilizers including those with polymer coatings and urease and nitrification inhibitors will make increased economic sense if they are used selectively under those environmental conditions where the potential $\mathrm{N}$ loss is high (Motavalli et al., 2012).

Management practices that improve or maintain soil health such as disturbing the soil less (reduced tillage), growing greater diversity of crops (in rotation and as diverse mixtures of cover crops), maintaining living roots in the soil as much as possible (with crops and cover crops), and keeping the soil covered with residue at all times will increase the resiliency of agroecosystems and decrease $\mathrm{N}$ losses (Zhang et al., 2015). These practices will likely result in decreased net nitrification while maintaining yields. The implementation of this knowledge to build more resiliency into our agricultural systems will need support from socioeconomic policy research.

\section{Management to Control Ammonium Substrate Availability}

The goal of $\mathrm{N}$ fertilizer rate recommendations is to estimate the gap between the $\mathrm{N}$ supplied by the soil and the $\mathrm{N}$ required for the crop to reach an optimum yield. In the United States and Europe, regional yield response curves and the fertilizercrop price ratio are often used to provide recommendations to farmers on economically optimal $\mathrm{N}$ application rates (Sawyer et al., 2006; Morris et al., 2018). Decreasing this basal N fertilizer rate will logically decrease $\mathrm{N}$ availability to nitrification but risks reducing yields enough to be an economic disadvantage and even increase overall environmental impacts. Therefore, rather than decrease overall $\mathrm{N}$ rate, approaches designed to improve NUE while maintaining yields may mitigate the risks associated with nitrification. Strategies for controlling $\mathrm{NH}_{4}^{+}$ substrate availability include timing of fertilization to coincide with rapid plant uptake, formulation of fertilizers as slow release forms and/or with inhibitors (e.g., urease inhibitors), keeping plants growing continuously to assimilate $\mathrm{N}$, and increasing microbial $\mathrm{N}$ immobilization (Figure 5).

\section{Timing of Fertilization to Coincide With Rapid Plant Uptake}

Generally, $\mathrm{N}$ fertilizers can be applied either before planting, as a sidedress, or as a split preplant-sidedress fertilizer treatment. Nitrogen is used more efficiently if applied during the growing season prior to the time of maximum plant uptake rate, as compared to application before the crop is planted (Sawyer et al., 2006). The timing of this split application may be based on crop stage or other plant or soil testing indicators such as the presidedress nitrate test (PSNT). Sidedress fertilization has been observed to reduce yield scaled $\mathrm{N}_{2} \mathrm{O}$ by $60 \%$ vs. fall fertilization (Abalos et al., 2016) and often results in improvements in NUE (Ma et al., 2010). Unfortunately, there remain large areas in the US Midwest and Canada where convenience favors anhydrous ammonia application to drier soils during the fall preceding spring planting. This approach is based on the principle that cold soil temperatures will slow nitrification sufficiently to retain fertilizer in the soil. Fall applications typically reduce NUE and must be timed carefully to wait until soil temperatures decrease enough to postpone nitrification activity until spring. Nitrification inhibitors are often combined with fall applications to delay nitrification but these may not remain effective through to the following spring.

\section{Keep Plants Growing Continuously to Assimilate N}

Competition with plants for available $\mathrm{N}$ can decrease nitrification and decrease nitrate accumulation. In many non-agricultural systems, plant $\mathrm{N}$ uptake occurs across seasons and $\mathrm{N}$ is retained in organic forms and in plant roots. Additionally, even when nitrification is occurring, there may be little net nitrification measurable because of nitrate use by plants and heterotrophic microbes (Stark and Hart, 1997; Norton and Stark, 2011). A range of $\mathrm{N}$ conserving mechanisms have evolved in natural 


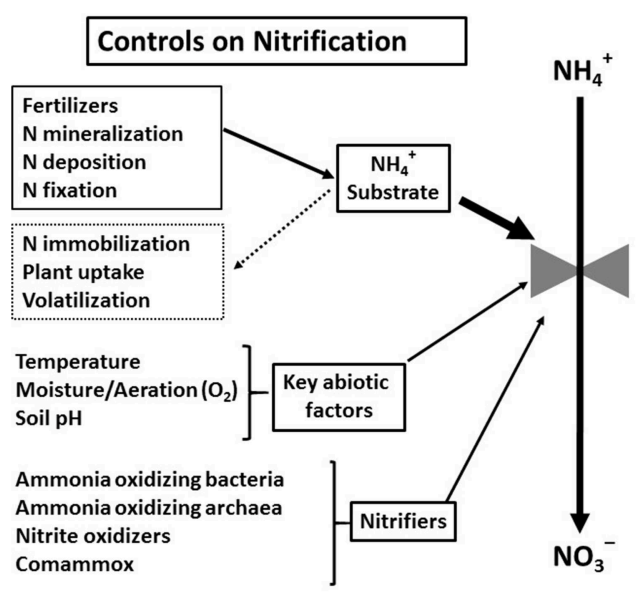

\begin{tabular}{|c|}
\hline Adaptive management practices \\
\hline 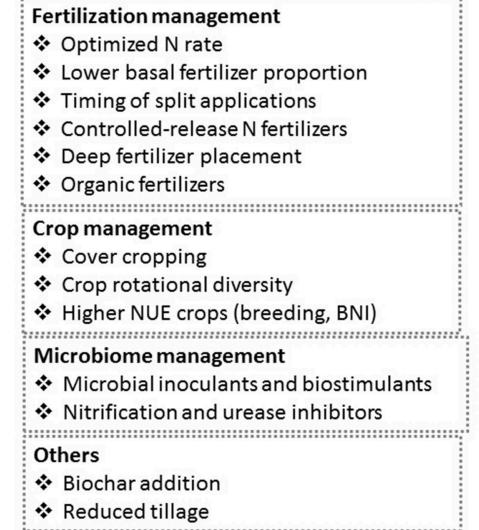 \\
\hline
\end{tabular}

FIGURE 5 | Relationship of controlling factors for nitrification to adaptive management practices promoting systems with higher nutrient use efficiency.

ecosystems including direct uptake of organic $\mathrm{N}$ by plants (by short-circuiting mineralization) and suppression of nitrification. These mechanisms essentially close the $\mathrm{N}$ cycle and facilitate soil organic $\mathrm{N}$ accumulation. The use of cover crops, living mulches and catch crops keeps living plant roots in the soil, adds organic matter to the system, and decreases nitrate accumulation and potential leaching (Abdalla et al., 2019). Cover crops must be managed carefully especially in drier climates to avoid decreases in the productivity of the primary crop due to water or nutrient uptake while promoting soil nitrate recycling.

\section{Controlled-Slow Release Fertilizers}

Slow/controlled release fertilizers are designed to better match the timing of nutrient release to the plant demand. Because of cost factors, their use in agricultural settings is limited although they are widely used in horticultural applications. Urea is one of the most widely used fertilizers in agriculture and is extremely soluble. Slow release coatings may be applied to limit solubility and delay urea hydrolysis and subsequent nitrification. Urea coatings include organic polymer coatings and inorganic coatings such as sulfur, their characteristics and merits of these materials have been reviewed recently (Naz and Sulaiman, 2016).

\section{Intensify Soil Internal N Cycling}

The use of inorganic fertilizers simplifies the soil internal $\mathrm{N}$ cycling process, leading to a high-nitrifying agricultural system (Figure 6A). Nitrate is often a dominant $\mathrm{N}$ pool, especially shortly after fertilization, in these agricultural soils. When the proportion of $\mathrm{N}$ supply to the plant by $\mathrm{N}$ fixation and $\mathrm{N}$ mineralization is increased relative to fertilizers sources then a low-nitrifying agricultural system is favored that reduces $\mathrm{N}$ loss and improves NUE (Figure 6B). Increased diversity of N cycling functional groups may also help retain $\mathrm{N}$ in soil. Intensified internal $\mathrm{N}$ cycling may be accomplished by the addition of high $\mathrm{C}$ organic amendments such as compost, manure, and biochar (Paustian et al., 2016); and by direct inoculation of $\mathrm{N}$-fixation and mineralization promoting bacteria and AMF (Hu and $\mathrm{He}, 2018)$.

\section{Inhibit Nitrifiers Directly} Nitrification Inhibitors

Nitrification inhibitors (NIs) slow the microbial conversion of ammonium-N to nitrate- $\mathrm{N}$ (nitrification), reducing the risk of loss through leaching or denitrification and thereby increasing the NUE of fertilizers. Many synthetic NIs act on the ammonia monooxygenase enzyme often as competitive suicide subtrates (for example acetylene) (McCarty, 1999). Several nitrification inhibitors that are widely used in agriculture include: (1) 2-chloro-6-(trichloromethyl) pyridine (nitrapyrin), (2) dicyandiamide (DCD), and (3) 3,4-dimethylepyrazole phosphate (DMPP). Urease inhibitors, such as $\mathrm{N}$-(n-butyl) thiophosphoric triamide (NBPT), are used to decrease urea hydrolysis and volatilization. Meta-analyses report that the application of urease and nitrification inhibitors significantly reduced inorganic $\mathrm{N}$ leaching $(-48 \%), \mathrm{N}_{2} \mathrm{O}$ emission $(-44 \%)$, and NO emission (-24\%) (Burzaco et al., 2014; Qiao et al., 2015; Thapa et al., 2016) while increasing crop yield (7.5\%) and NUE (12.9\%) (Abalos et al., 2014). The beneficial effect of nitrification inhibitors may depend on the environment (e.g., soil $\mathrm{pH}$ and texture) and other management factors (e.g., irrigation and $\mathrm{N}$ fertilizer rate) (Abalos et al., 2014). The longevity of the inhibitors under soil conditions as affected by temperature is of key importance for their effectiveness (Menéndez et al., 2012; Guardia et al., 2018). Reaching the optimum balance between $\mathrm{N}$ oxides and greenhouse gas losses, $\mathrm{N}$ efficiency and crop yields often indicates the use of nitrification inhibitors with liquid organic sources such as manure slurries (Guardia et al., 2017). However, the use of nitrification inhibitors also increases cost, potential for $\mathrm{NH}_{3}$ emission and the risk of environmental contamination (Kim et al., 2012; Qiao et al., 2015). Recently, nitrapyrin has been detected in streams, suggesting offsite transport of this $\mathrm{N}$ stabilizing compound (Woodward et al., 2016) and DCD residues were detected in milk in New Zealand resulting in the suspension of DCD use in pastures (Thapa et al., 2016). Chemical nitrification inhibitors are not permitted in certified organic management systems, so organic alternatives are 

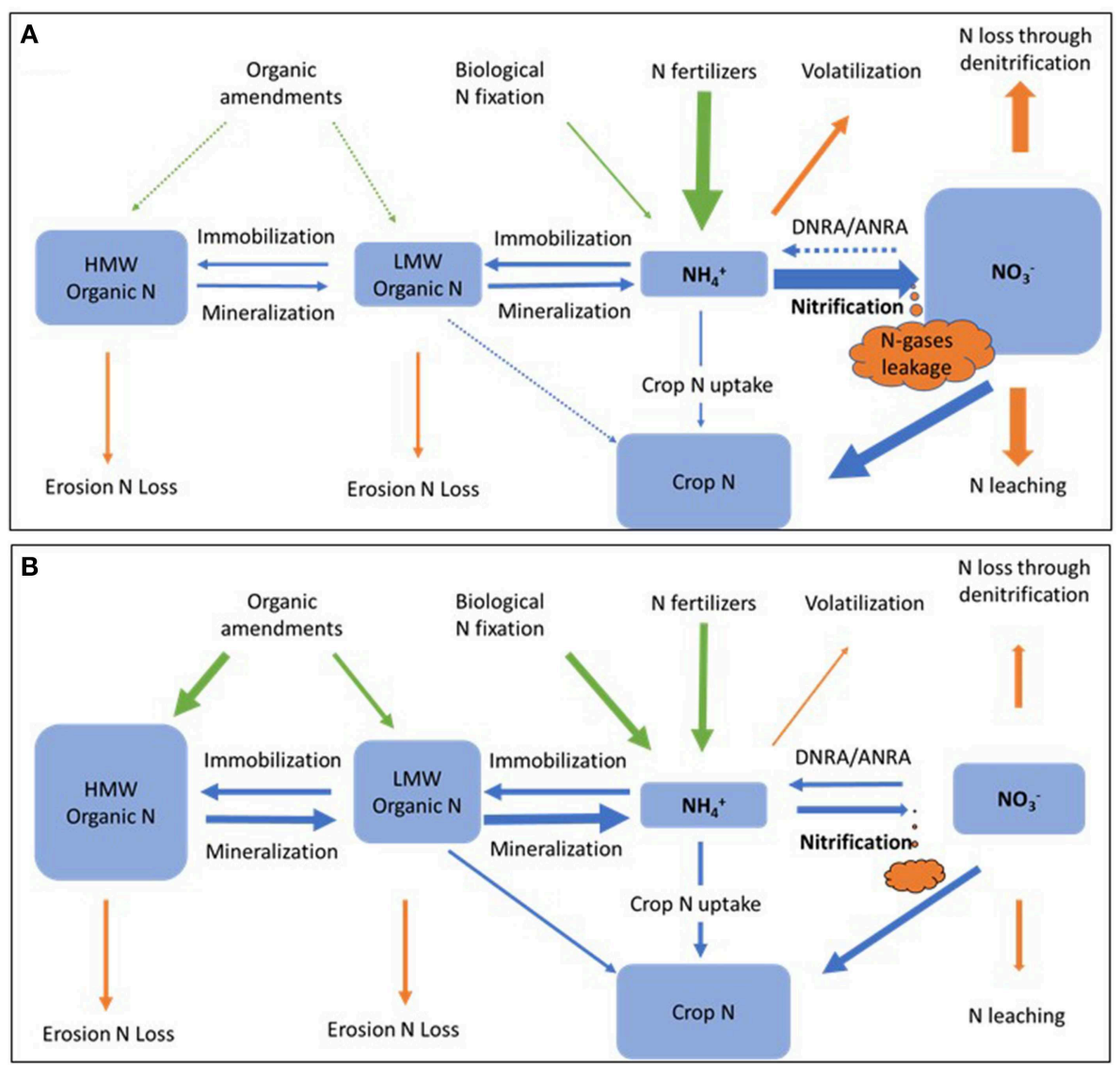

FIGURE 6 | Hypothetic nitrogen pools and flows of high-nitrifying (A) and low-nitrifying (B) agricultural systems. Arrows represent nitrogen inputs (green), losses (orange), and transformations (blue). HMW, high molecular weight; LMW, low molecular weight; DNRA, dissimilatory nitrate reduction to ammonium; ANRA, assimilatory nitrate reduction to ammonium.

needed for management of nitrification and the use of neem seed oil (Opoku et al., 2014) has been suggested for this purpose.

\section{Biological Nitrification Inhibition}

Biological nitrification inhibition (BNI) is the ability of certain plant roots to impede soil nitrification through the production of biological inhibitors (Subbarao et al., 2013, 2017; Byrnes et al., 2017; Coskun et al., 2017). If BNI may be exploited to reduce nitrification in high nitrifying, low NUE systems then fertilizer use and loss may be decreased with associated decreases in GHG production. Some BNI's have been isolated from tropical pasture grasses that are adapted to low- $\mathrm{N}$ environments, in particular Brachiaria spp. have high BNI-activity in root systems and among field crops, sorghum (Sorghum bicolor) has been observed to produce biological nitrification inhibitors (Subbarao et al., 2015). Incorporation of these crops into rotations or pasture systems may help to retain $\mathrm{N}$ in these soils systems and increase soil $\mathrm{N}$ pools. If BNI traits from these plants could be transferred to grain crops, there may be potential benefits to NUE but unknown but likely tradeoffs to productivity. The search continues for biological nitrification inhibitors for the major grain crops especially maize.
Both plants and microbes may produce chemical compounds to inhibit nitrification to compete for ammonium in the rhizosphere. While most studies on BNI focus on plant root exudates; microbes could also produce compounds that inhibit nitrification. Soil microbes produce a wide array of signaling molecules and hydrocarbons including ethylene (Ladygina et al., 2006) that might be exploited for their inhibitory effects.

\section{MANAGING NITRIFICATION UNDER A CHANGING CLIMATE}

The goal of reducing $\mathrm{N}$ losses from agricultural systems under changing climatic conditions is inherently complex spanning from technical through socio-economic approaches. Management that promotes shifting toward low nitrifying agricultural systems is part of a potential solution. Reducing the residence time and amount of inorganic $\mathrm{N}$ pools in agricultural soils while maintaining sufficient $\mathrm{N}$ fertility will require system based management. Reductions in the seasonal use of bare fallow, use of cover crops, increases in crop rotational diversity and 
perennial crops may increase the capacity for $\mathrm{N}$ retention in agricultural soils (Figures 5, 6). Unfortunately, projected impacts of changing climate may make our current mitigation efforts less effective (Le Roux et al., 2016; Bowles et al., 2018). Climate change affects nitrification in agriculture primarily through raising temperatures and the amount and intensity of rainfall (Robertson et al., 2013; Bowles et al., 2018). This combination of factors will increase the propensity for nitrification and subsequent $\mathrm{N}$ loss through leaching and denitrification. The controlling factors for nitrification described above have been used as drivers for the rate of nitrification in the process based models DayCent (Del Grosso et al., 2012) and DNDC (Li, 2007) (Table 1). In both of these systems nitrification is a function of $\mathrm{NH}_{4}^{+}$availability, water content, temperature, $\mathrm{pH}$, and texture (Grant et al., 2016) although DNDC more explicitly drives microbial reactions by consideration of the redox balance in the soil and the volumetric fraction of the soil that is anaerobic (Li, 2007). Trait-Based models of nitrification predict that there may be changes in ammonia and nitrite oxidizer communities driven by global change contributing to feedback effects (Bouskill et al., 2012; Le Roux et al., 2016). Some factors that are under the control of land managers include: amount, form and application timing of $\mathrm{N}$ fertilizers, the use of nitrification inhibitors, and the amount and timing of water application in irrigated systems (Figure 5). These factors may be used to parameterize farm-scale (Del Grosso et al., 2016; Paustian et al., 2018) or trait-based models to advise management. However, factors such as the timing and intensity of rainfall, extreme drought events, and the timing of mineralization remain challenging management targets. In the future under a changing climate, elevated temperature and more variable precipitation will likely increase $\mathrm{N}$ mineralization and nitrification leading to even more urgent need to manage nitrification and prevent $\mathrm{N}$ losses from agriculture (Bowles et al., 2018).

\section{REFERENCES}

Abalos, D., Jeffery, S., Sanz-Cobena, A., Guardia, G., and Vallejo, A. (2014). Meta-analysis of the effect of urease and nitrification inhibitors on crop productivity and nitrogen use efficiency. Agric. Ecosyst. Environ. 189, 136-144. doi: 10.1016/j.agee.2014.03.036

Abalos, D., Smith, W. N., Grant, B. B., Drury, C. F., MacKell, S., and Wagner-Riddle, C. (2016). Scenario analysis of fertilizer management practices for $\mathrm{N} 2 \mathrm{O}$ mitigation from corn systems in Canada. Sci. Total Environ. 573, 356-365. doi: 10.1016/j.scitotenv.2016. 08.153

Abdalla, M., Hastings, A., Cheng, K., Yue, Q., Chadwick, D., Espenberg, M., et al. (2019). A critical review of the impacts of cover crops on nitrogen leaching, net greenhouse gas balance and crop productivity. Glob. Chang. Biol. 25, 2530-2543. doi: 10.1111/gcb.14644

Abdalla, M., Jones, M., Yeluripati, J., Smith, P., Burke, J., and Williams, M. (2010). Testing DayCent and DNDC model simulations of $\mathrm{N}(2) \mathrm{O}$ fluxes and assessing the impacts of climate change on the gas flux and biomass production from a humid pasture. Atmos. Environ. 44, 2961-2970. doi: 10.1016/j.atmosenv.2010.05.018

Abell, G. C. J., Banks, J., Ross, D. J., Keane, J. P., Robert, S. S., Revill, A. T., et al. (2011). Effects of estuarine sediment hypoxia on nitrogen fluxes and ammonia oxidizer gene transcription. FEMS Microbiol. Ecol. 75, 111-122. doi: 10.1111/j.1574-6941.2010.00988.x

\section{SUMMARY AND FUTURE DIRECTIONS}

We review the controlling factors on the rate and extent of nitrification common in agricultural soils from temperate regions including substrate supply, environmental conditions, abundance and diversity of nitrifiers, and plant and microbial interaction with nitrifiers. Two main strategies for managing nitrification are to control ammonium substrate availability or inhibit nitrifiers directly. We propose four key future directions: (1) focus on enzymes involved in nitrification using proteomics-direct extraction of enzymes or fluorescently labeling key enzymes, (2) link ecophysiology in soil to sequence variants for trait-based modeling, (3) discover novel nitrification inhibitors, survey rootzone microbes and cultivars of major crop plants for inhibitory compounds, and (4) improve nitrification management modeling, especially for changing climate scenarios.

\section{AUTHOR CONTRIBUTIONS}

All authors listed have made a substantial, direct and intellectual contribution to the work, and approved it for publication.

\section{FUNDING}

This work was supported by grants from the USDA NIFA Award 2011-67019-30178 and 2016-35100-25091 and from the Utah Agricultural Experiment Station, Utah State University and approved as journal paper 9174 .

\section{SUPPLEMENTARY MATERIAL}

The Supplementary Material for this article can be found online at: https://www.frontiersin.org/articles/10.3389/fmicb. 2019.01931/full\#supplementary-material

Alves, R. J. E., Wanek, W., Zappe, A., Richter, A., Svenning, M. M., Schleper, C., et al. (2013). Nitrification rates in Arctic soils are associated with functionally distinct populations of ammonia-oxidizing archaea. ISME J. 7, 1620-1631. doi: 10.1038/ismej.2013.35

Arp, D. J., Sayavedra-Soto, L. A., and Hommes, N. G. (2002). Molecular biology and biochemistry of ammonia oxidation by Nitrosomonas europaea. Arch. Microbiol. 178, 250-255. doi: 10.1007/s00203-002-0452-0

Attard, E., Poly, F., Commeaux, C., Laurent, F., Terada, A., Smets, B. F., et al. (2010). Shifts between nitrospira-and nitrobacter-like nitrite oxidizers underlie the response of soil potential nitrite oxidation to changes in tillage practices. Environ. Microbiol. 12, 315-326. doi: 10.1111/j.1462-2920.2009. 02070.x

Bennett, K., Sadler, N. C., Wright, A. T., Yeager, C., and Hyman, M. R. (2016). Activity-based protein profiling of ammonia monooxygenase in Nitrosomonas europaea. Appl. Environ. Microbiol. 82, 2270-2279. doi: 10.1128/AEM.03556-15

Bertagnolli, A. D., McCalmont, D., Meinhardt, K. A., Fransen, S. C., Strand, S., Brown, S., et al. (2016). Agricultural land usage transforms nitrifier population ecology. Environ. Microbiol. 18, 1918-1929. doi: 10.1111/1462-2920.13114

Bollmann, A., Bar-Gilissen, M. J., and Laanbroek, H. J. (2002). Growth at low ammonium concentrations and starvation response as potential factors involved in niche differentiation among ammonia-oxidizing bacteria. Appl. Environ. Microbiol. 68, 4751-4757. doi: 10.1128/AEM.68.10.4751-4757.2002

Bollmann, A., Schmidt, I., Saunders, A. M., and Nicolaisen, M. H. (2005). Influence of starvation on potential ammonia-oxidizing activity and amoA 
mRNA levels of Nitrosospira briensis. Appl. Environ. Microbiol. 71, 1276-1282. doi: 10.1128/AEM.71.3.1276-1282.2005

Booth, M. S., Stark, J. M., and Rastetter, E. (2005). Controls on nitrogen cycling in terrestrial ecosystems: a synthetic analysis of literature data. Ecol. Monogr. 75, 139-157. doi: 10.1890/04-0988

Bouskill, N., Tang, J., Riley, W., and Brodie, E. (2012). Trait-based representation of biological nitrification: model development, testing, and predicted community composition. Front. Microbiol. 3:364. doi: 10.3389/fmicb.2012. 00364

Bowles, T. M., Atallah, S. S., Campbell, E. E., Gaudin, A. C., Wieder, W. R., and Grandy, A. S. (2018). Addressing agricultural nitrogen losses in a changing climate. Nat. Sustain. 1:399. doi: 10.1038/s41893-018-0106-0

Breuillin-Sessoms, F., Venterea, R. T., Sadowsky, M. J., Coulter, J. A., Clough, T. J., and Wang, P. (2017). Nitrification gene ratio and free ammonia explain nitrite and nitrous oxide production in urea-amended soils. Soil Biol. Biochem. 111, 143-153. doi: 10.1016/j.soilbio.2017.04.007

Burger, M., and Jackson, L. E. (2003). Microbial immobilization of ammonium and nitrate in relation to ammonification and nitrification rates in organic and conventional cropping systems. Soil Biol. Biochem. 35, 29-36. doi: 10.1016/S0038-0717(02)00233-X

Burger, M., and Jackson, L. E. (2004). Plant and microbial nitrogen use and turnover: rapid conversion of nitrate to ammonium in soil with roots. Plant Soil. 266, 289-301. doi: 10.1007/s11104-005-1362-0

Burton, S. A. Q., and Prosser, J. I. (2001). Autotrophic ammonia oxidation at low pH through urea hydrolysis. Appl. Environ. Microbiol. 67, 2952-2957. doi: 10.1128/AEM.67.7.2952-2957.2001

Burzaco, J. P., Ciampitti, I. A., and Vyn, T. J. (2014). Nitrapyrin impacts on maize yield and nitrogen use efficiency with spring-applied nitrogen: field studies vs. meta-analysis comparison. Agron. J. 106, 753-760. doi: 10.2134/agronj2013.0043

Byrnes, R. C., Nùñez, J., Arenas, L., Rao, I., Trujillo, C., Alvarez, C., et al. (2017). Biological nitrification inhibition by Brachiaria grasses mitigates soil nitrous oxide emissions from bovine urine patches. Soil Biol. Biochem. 107, 156-163. doi: 10.1016/j.soilbio.2016.12.029

Carey, C. J., Dove, N. C., Beman, J. M., Hart, S. C., and Aronson, E. L. (2016). Metaanalysis reveals ammonia-oxidizing bacteria respond more strongly to nitrogen addition than ammonia-oxidizing archaea. Soil Biol. Biochem. 99, 158-166. doi: 10.1016/j.soilbio.2016.05.014

Cavigelli, M. A., Del Grosso, S. J., Liebig, M. A., Snyder, C. S., Fixen, P. E., Venterea, R. T., et al. (2012). US agricultural nitrous oxide emissions: context, status, and trends. Front. Ecol. Environ. 10, 537-546. doi: 10.1890/120054

Chain, P. S. G., Lamerdin, J., Larimer, F., Regala, W., Lao, V., Land, M., et al. (2003). Complete genome sequence of the ammonia-oxidizing bacterium and obligate chemolithoautotroph Nitrosomonas europaea. J. Bacteriol. 185, 2759-2773. doi: 10.1128/JB.185.9.2759-2773.2003

Chen, Y.-L., Chen, B.-D., Hu, Y.-J., Li, T., Zhang, X., Hao, Z.-P., et al. (2013). Direct and indirect influence of arbuscular mycorrhizal fungi on abundance and community structure of ammonia oxidizing bacteria and archaea in soil microcosms. Pedobiologia. 56, 205-212. doi: 10.1016/j.pedobi.2013. 07.003

Choi, J., Kotay, S. M., and Goel, R. (2010). Various physico-chemical stress factors cause prophage induction in Nitrosospira multiformis 25196- an ammonia oxidizing bacteria. Water Res. 44, 4550-4558. doi: 10.1016/j.watres.2010.04.040

Clarke, K., and Beegle, D. B. (2014). "Nutrient management to improve nitrogen use efficiency and reduce environmental losses," in Agronomy Facts, ed P. S. Extension (State College, PA: Pennsylvania State University Extension). Available online at: https://extension.psu.edu/programs/nutrientmanagement/educational/soil-fertility/nutrient-management-to-improvenitrogen-use-efficiency-and-reduce-environmental-losses/extension publication_file (accessed August 14, 2019).

Cookson, W. R., Cornforth, I. S., and Rowarth, J. S. (2002). Winter soil temperature $\left(2-15^{\circ} \mathrm{C}\right)$ effects on nitrogen transformations in clover green manure amended or unamended soils; a laboratory and field study. Soil Biol. Biochem. 34, 1401-1415. doi: 10.1016/S0038-0717(02)00083-4

Coskun, D., Britto, D. T., Shi, W., and Kronzucker, H. J. (2017). Nitrogen transformations in modern agriculture and the role of biological nitrification inhibition. Nat. Plants 3:17074. doi: 10.1038/nplants.2017.74
Courty, P.-E., Buée, M., Diedhiou, A. G., Frey-Klett, P., Le Tacon, F., Rineau, F., et al. (2010). The role of ectomycorrhizal communities in forest ecosystem processes: new perspectives and emerging concepts. Soil Biol. Biochem. 42, 679-698. doi: 10.1016/j.soilbio.2009.12.006

Daebeler, A., Bodelier, P. L. E., Hefting, M. M., Rütting, T., Jia, Z., and Laanbroek, H. J. (2017). Soil warming and fertilization altered rates of nitrogen transformation processes and selected for adapted ammonia-oxidizing archaea in sub-arctic grassland soil. Soil Biol. Biochem. 107, 114-124. doi: 10.1016/j.soilbio.2016.12.013

Daims, H., Lebedeva, E. V., Pjevac, P., Han, P., Herbold, C., Albertsen, M., et al. (2015). Complete nitrification by Nitrospira bacteria. Nature 528, 504-509. doi: $10.1038 /$ nature 16461

De Boer, W., and Kowalchuk, G. A. (2001). Nitrification in acid soils: micro-organisms and mechanisms. Soil Biol. Biochem. 33, 853-866. doi: 10.1016/S0038-0717(00)00247-9

De Boer, W., and Laanbroek, H. J. (1989). Ureolytic nitrification at low pH by Nitrosospira spec. Arch. Microbiol. 152, 178-181. doi: 10.1007/BF00456098

Del Grosso, S. J., Ahuja, L. R., and Parton, W. J. (2016). "Modeling GHG emissions and carbon changes in agricultural and forest systems to guide mitigation and adaptation: synthesis and future needs," in Synthesis and Modeling of Greenhouse Gas Emissions and Carbon Storage in Agricultural and Forest Systems to Guide Mitigation and Adaptation, eds S. Del Grosso, L. Ahuja and W. Parton (Madison, WI: American Society of Agronomy, Inc., Crop Science Society of America, Inc., and Soil Science Society of America, Inc.), 305-318. doi: 10.2134/advagricsystmodel6.2013.0008

Del Grosso, S. J., Ojima, D. S., Parton, W. J., Stehfest, E., Heistemann, M., DeAngelo, B., et al. (2009). Global scale DAYCENT model analysis of greenhouse gas emissions and mitigation strategies for cropped soils. Glob. Planet. Change 67, 44-50. doi: 10.1016/j.gloplacha.2008.12.006

Del Grosso, S. J., Parton, W. J., Adler, P. R., Davis, S. C., Keough, C., and Marx, E. (2012). "Chapter 14 - DayCent model simulations for estimating soil carbon dynamics and greenhouse gas fluxes from agricultural production systems," in Managing Agricultural Greenhouse Gases, eds M. A. Liebig, A. J. Franzluebbers and R. F. Follett (San Diego, CA: Academic Press), 241-250. doi: 10.1016/B978-0-12-386897-8.00014-0

Di, H. J., Cameron, K. C., Shen, J. P., Winefield, C. S., O'Callaghan, M., Bowatte, S., et al. (2010). Ammonia-oxidizing bacteria and archaea grow under contrasting soil nitrogen conditions. FEMS Microbiol. Ecol. 72, 386-394. doi: 10.1111/j.1574-6941.2010.00861.x

Dolinšek, J., Lagkouvardos, I., Wanek, W., Wagner, M., and Daims, H. (2013). Interactions of nitrifying bacteria and heterotrophs: identification of a Micavibrio-like putative predator of Nitrospira spp. Appl. Environ. Microbiol. 79, 2027-2037. doi: 10.1128/AEM.03408-12

FAO (2015). World Fertilizer Trends and Outlook to 2018. Rome: Food and Agriculture Organization of the United Nations.

Fierer, N., Carney, K. M., Horner-Devine, M. C., and Megonigal, J. P. (2009). The biogeography of ammonia-oxidizing bacterial communities in soil. Microb. Ecol. 58, 435-445. doi: 10.1007/s00248-009-9517-9

Finzi, A. C., Abramoff, R. Z., Spiller, K. S., Brzostek, E. R., Darby, B. A., Kramer, M. A., et al. (2015). Rhizosphere processes are quantitatively important components of terrestrial carbon and nutrient cycles. Glob. Chang. Biol. 21, 2082-2094. doi: $10.1111 / \mathrm{gcb} .12816$

Fowler, D., Coyle, M., Skiba, U., Sutton, M. A., Cape, J. N., Reis, S., et al. (2013). The global nitrogen cycle in the twenty-first century. Philosop. Trans. R. Soc. B Biol. Sci. 368:20130164. doi: 10.1098/rstb.2013.0164

Freitag, T. E., Chang, L., Clegg, C. D., and Prosser, J. I. (2005). Influence of inorganic nitrogen management regime on the diversity of nitrite-oxidizing bacteria in agricultural grassland soils. Appl. Environ. Microbiol. 71, 8323-8334. doi: 10.1128/AEM.71.12.8323-8334.2005

Galloway, J. N., and Cowling, E. B. (2002). Reactive nitrogen and the world: 200 years of change. Ambio 31, 64-71. doi: 10.1579/0044-7447-31.2.64

Giguere, A. T., Taylor, A. E., Myrold, D. D., and Bottomley, P. J. (2015). Nitrification responses of soil ammonia-oxidizing archaea and bacteria to ammonium concentrations. Soil Sci. Soc. Am. J. 79, 1366-1374. doi: 10.2136/sssaj2015.03.0107

Giguere, A. T., Taylor, A. E., Suwa, Y., Myrold, D. D., and Bottomley, P. J. (2017). Uncoupling of ammonia oxidation from nitrite oxidation: impact upon nitrous 
oxide production in non-cropped Oregon soils. Soil Biol. Biochem. 104, 30-38. doi: 10.1016/j.soilbio.2016.10.011

Gilhespy, S. L., Anthony, S., Cardenas, L., Chadwick, D., del Prado, A., Li, C. S., et al. (2014). First 20 years of DNDC (DeNitrification DeComposition): model evolution. Ecol. Modell. 292, 51-62. doi: 10.1016/j.ecolmodel.2014. 09.004

Giltrap, D. L., Li, C., and Saggar, S. (2010). DNDC: a process-based model of greenhouse gas fluxes from agricultural soils. Agricult. Ecosyst. Environ. 136, 292-300. doi: 10.1016/j.agee.2009.06.014

Graham, E. B., Knelman, J. E., Schindlbacher, A., Siciliano, S., Breulmann, M., Yannarell, A., et al. (2016). Microbes as engines of ecosystem function: when does community structure enhance predictions of ecosystem processes? Front. Microbiol. 7:214. doi: 10.3389/fmicb.2016.00214

Grant, B. B., Smith, W. N., Campbell, C. A., Desjardins, R. L., Lemke, R. L., Kröbel, R., et al. (2016). "Comparison of DayCent and DNDC models: case studies using data from long-term experiments on the canadian prairies," in Synthesis and Modeling of Greenhouse Gas Emissions and Carbon Storage in Agricultural and Forest Systems to Guide Mitigation and Adaptation, eds S. Del Grosso, L. Ahuja and W. Parton (Madison, WI: American Society of Agronomy, Inc., Crop Science Society of America, Inc., and Soil Science Society of America, Inc.), 21-58. doi: 10.2134/advagricsystmodel6.2013.0035

Grant, R. F. (1994). Simulation of ecological controls on nitrification. Soil Biol. Biochem. 26, 305-315. doi: 10.1016/0038-0717(94)90279-8

Grant, R. F. (2001). "A review of the canadian ecosystem model-ecosys," in Modeling Carbon and Nitrogen Dynamics for Soil Management, eds M. J. Shaffer, L. Ma and S. K. Hansen (Boca Raton. FL: CRC Press LLC), 173-264. doi: 10.1201/9781420032635.ch6

Grant, R. F. (2014). Nitrogen mineralization drives the response of forest productivity to soil warming: modelling in ecosys vs. measurements from the harvard soil heating experiment. Ecol. Modell. 288, 38-46. doi: 10.1016/j.ecolmodel.2014.05.015

Grant, R. F., and Pattey, E. (2003). Modelling variability in N2O emissions from fertilized agricultural fields. Soil Biol. Biochem. 35, 225-243. doi: 10.1016/S0038-0717(02)00256-0

Grant, R. F., Pattey, E., Goddard, T. W., Kryzanowski, L. M., and Puurveen, H. (2006). Modeling the effects of fertilizer application rate on nitrous oxide emissions. Soil Sci. Soc. Am. J. 70, 235-248. doi: 10.2136/sssaj2005.0104

Guardia, G., Cangani, M. T., Sanz-Cobena, A., Junior, J. L., and Vallejo, A. (2017). Management of pig manure to mitigate NO and yield-scaled N2O emissions in an irrigated mediterranean crop. Agric. Ecosyst. Environ. 238, 55-66. doi: 10.1016/j.agee.2016.09.022

Guardia, G., Marsden, K. A., Vallejo, A., Jones, D. L., and Chadwick, D. R. (2018). Determining the influence of environmental and edaphic factors on the fate of the nitrification inhibitors DCD and DMPP in soil. Sci. Total Environ. 624, 1202-1212. doi: 10.1016/j.scitotenv.2017.12.250

Gubry-Rangin, C., Hai, B., Quince, C., Engel, M., Thomson, B. C., James, P., et al. (2011). Niche specialization of terrestrial archaeal ammonia oxidizers. Proc. Natl. Acad. Sci.U.S.A. 108, 21206-21211. doi: 10.1073/pnas.1109000108

Gubry-Rangin, C., Nicol, G. W., and Prosser, J. I. (2010). Archaea rather than bacteria control nitrification in two agricultural acidic soils. FEMS Microbiol. Ecol. 74, 566-574. doi: 10.1111/j.1574-6941.2010.00971.x

Gubry-Rangin, C., Novotnik, B., Mandič-Mulec, I., Nicol, G. W., and Prosser, J. I. (2017). Temperature responses of soil ammonia-oxidising archaea depend on pH. Soil Biol. Biochem. 106, 61-68. doi: 10.1016/j.soilbio.2016.12.007

Habteselassie, M. Y., Stark, J. M., Miller, B. E., Thacker, S. G., and Norton, J. M. (2006). Gross nitrogen transformations in an agricultural soil after repeated dairy-waste application. Soil Sci. Soc. Am. J. 70, 1338-1348. doi: 10.2136/sssaj2005.0190

Hamonts, K., Balaine, N., Moltchanova, E., Beare, M., Thomas, S., Wakelin, S. A., et al. (2013). Influence of soil bulk density and matric potential on microbial dynamics, inorganic $\mathrm{N}$ transformations, $\mathrm{N} 2 \mathrm{O}$ and N2 fluxes following urea deposition. Soil Biol. Biochem. 65, 1-11. doi: 10.1016/j.soilbio.2013.05.006

Han, S., Luo, X., Liao, H., Nie, H., Chen, W., and Huang, Q. (2017). Nitrospira are more sensitive than Nitrobacter to land management in acid, fertilized soils of a rapeseed-rice rotation field trial. Sci. Total Environ. 599-600, 135-144. doi: 10.1016/j.scitotenv.2017.04.086

Han, S., Zeng, L., Luo, X., Xiong, X., Wen, S., Wang, B., et al. (2018). Shifts in Nitrobacter- and Nitrospira-like nitrite-oxidizing bacterial communities under long-term fertilization practices. Soil Biol. Biochem. 124, 118-125. doi: 10.1016/j.soilbio.2018.05.033

Han, W.-Y., Xu, J.-M., Yi, X.-Y., and Lin, Y.-D. (2012). Net and gross nitrification in tea soils of varying productivity and their adjacent forest and vegetable soils. Soil Sci. Plant Nutr. 58, 173-182. doi: 10.1080/00380768.2012.664783

Hart, S. C., Stark, J. M., Davidson, E. A., and Firestone, M. K. (1994). "Nitrogen mineralization, immobilization and nitrification," in Methods of Soil Analysis. Part 2, Microbiological and Biochemical Properties, eds R. W. Weaver, S. Angle, P. Bottomly, D. Bezdicek, S. Smith, A. Tabatabai and A. Wollum. (Madison, WI: Soil Science Society America), 985-1018.

Hatzenpichler, R. (2012). Diversity, physiology, and niche differentiation of ammonia-oxidizing Archaea. Appl. Environ. Microbiol. 78, 7501-7510. doi: 10.1128/AEM.01960-12

Hawkes, C. V., DeAngelis, K. M., and Firestone, M. K. (2007). "CHAPTER 1 - root interactions with soil microbial communities and processes," in The Rhizosphere, eds Z. G. Cardon and J. L. Whitbeck (Burlington, NJ: Academic Press), 1-29. doi: 10.1016/B978-012088775-0/50003-3

Hawkins, S. A., Robinson, K. G., Layton, A. C., and Sayler, G. S. (2007). Response of Nitrobacter spp. ribosomal gene and transcript abundance following nitrite starvation and exposure to mechanistically distinct inhibitors. Environ. Sci. Technol. 42, 901-907. doi: 10.1021/es0716002

He, J. Z., Shen, J., Zhang, L., Zhu, Y., Zheng, Y., Xu, M., et al. (2007). Quantitative analyses of the abundance and composition of ammoniaoxidizing bacteria and ammonia-oxidizing archaea of a Chinese upland red soil under long-term fertilization practices. Environ. Microbiol. 9, 2364-2374. doi: 10.1111/j.1462-2920.2007.01358.x

Heil, J., Vereecken, H., and Brüggemann, N. (2016). A review of chemical reactions of nitrification intermediates and their role in nitrogen cycling and nitrogen trace gas formation in soil. Eur. J. Soil Sci. 67, 23-39. doi: 10.1111/ejss.12306

Herrmann, M., Hadrich, A., and Kusel, K. (2012). Predominance of thaumarchaeal ammonia oxidizer abundance and transcriptional activity in an acidic fen. Environ. Microbiol. 14, 3013-3025. doi: 10.1111/j.1462-2920.2012.02882.x

Hooper, A. B., Vannelli, T., Bergmann, D. J., and Arciero, D. M. (1997). Enzymology of the oxidation of ammonia to nitrite by bacteria. Antonie Van Leeuwenhoek 71, 59-67. doi: 10.1023/A:1000133919203

$\mathrm{Hu}, \mathrm{H} .-\mathrm{W}$. , and He, J.-Z. (2018). Manipulating the soil microbiome for improved nitrogen management. Microbiol. Aust. 39, 24-27. doi: 10.1071/MA18007

Inselsbacher, E., Hinko-Najera Umana, N., Stange, F. C., Gorfer, M., Schüller, E., Ripka, K., et al. (2010). Short-term competition between crop plants and soil microbes for inorganic N fertilizer. Soil Biol. Biochem. 42, 360-372. doi: 10.1016/j.soilbio.2009.11.019

Inselsbacher, E., Wanek, W., Strauss, J., Zechmeister-Boltenstern, S., and Mueller, C. (2013). A novel N-15 tracer model reveals: plant nitrate uptake governs nitrogen transformation rates in agricultural soils. Soil Biol. Biochem. 57, 301-310. doi: 10.1016/j.soilbio.2012.10.010

Jia, Z. J., and Conrad, R. (2009). Bacteria rather than archaea dominate microbial ammonia oxidation in an agricultural soil. Environ. Microbiol. 11, 1658-1671. doi: 10.1111/j.1462-2920.2009.01891.x

Jiang, Q. Q., and Bakken, L. R. (1999). Comparison of Nitrosospira strains isolated from terrestrial environments. FEMS Microbiol. Ecol. 30, 171-186. doi: 10.1111/j.1574-6941.1999.tb00646.x

Jiang, Y., Jin, C., and Sun, B. (2014). Soil aggregate stratification of nematodes and ammonia oxidizers affects nitrification in an acid soil. Environ. Microbiol. 16, 3083-3094. doi: 10.1111/1462-2920.12339

Kaiser, J. (2001). The other global pollutant: nitrogen proves tough to curb. Science 294:1268. doi: 10.1126/science.294.5545.1268

Kerou, M., Offre, P., Valledor, L., Abby, S. S., Melcher, M., Nagler, M., et al. (2016). Proteomics and comparative genomics of Nitrososphaera viennensis reveal the core genome and adaptations of archaeal ammonia oxidizers. Proc. Natl Acad. Sci.U.S.A. 113, E7937-E7946. doi: 10.1073/pnas.1601212113

Kim, D.-G., Saggar, S., and Roudier, P. (2012). The effect of nitrification inhibitors on soil ammonia emissions in nitrogen managed soils: a meta-analysis. Nutr. Cycl. Agroecosyst. 93, 51-64. doi: 10.1007/s10705-012-9498-9

Kits, K. D., Sedlacek, C. J., Lebedeva, E. V., Han, P., Bulaev, A., Pjevac, P., et al. (2017). Kinetic analysis of a complete nitrifier reveals an oligotrophic lifestyle. Nature 549:269. doi: 10.1038/nature23679

Koch, H., Lucker, S., Albertsen, M., Kitzinger, K., Herbold, C., Spieck, E., et al. (2015). Expanded metabolic versatility of ubiquitous nitrite-oxidizing bacteria 
from the genus Nitrospira. Proc. Natl. Acad. Sci. U.S.A. 112, 11371-11376. doi: 10.1073/pnas.1506533112

Koch, H., van Kessel, M. A. H. J., and Lücker, S. (2019). Complete nitrification: insights into the ecophysiology of comammox Nitrospira. Appl. Microbiol. Biotechnol. 103, 177-189. doi: 10.1007/s00253-018-9486-3

Koops, H. P., Bottcher, B., Moller, U. C., Pommerening-Roser, A., and Stehr, G. (1991). Classification of eight new species of ammonia-oxidizing bacteria: Nitrosomonas communis sp nov., Nitrosomonas ureae sp nov., Nitrosomonas aestuarii sp nov., Nitrosomonas marina sp nov., Nitrosomonas nitrosa sp nov., Nitrosomonas oligotropha sp nov., Nitrosomonas halophila sp nov. J. Gen. Microbiol. 137, 1689-1699. doi: 10.1099/00221287-137-7-1689

Koops, H. P., and Pommerening-Roser, A. (2001). Distribution and ecophysiology of the nitrifying bacteria emphasizing cultured species. FEMS Microbiol. Ecol. 37, 1-9. doi: 10.1111/j.1574-6941.2001.tb00847.x

Koper, T. E., El-Sheikh, A. F., Norton, J. M., and Klotz, M. G. (2004). Ureaseencoding genes in ammonia-oxidizing bacteria. Appl. Environ. Microbiol. 70, 2342-2348. doi: 10.1128/AEM.70.4.2342-2348.2004

Kozlowski, J. A., Stieglmeier, M., Schleper, C., Klotz, M. G., and Stein, L. Y. (2016). Pathways and key intermediates required for obligate aerobic ammoniadependent chemolithotrophy in bacteria and Thaumarchaeota. ISME J. 10, 1836-1845. doi: 10.1038/ismej.2016.2

Kunhikrishnan, A., Thangarajan, R., Bolan, N. S., Xu, Y., Mandal, S., Gleeson, D. B., et al. (2016). "Chapter one - functional relationships of soil acidification, liming, and greenhouse gas flux," in Advances in Agronomy, ed. D. L. Sparks (San Diego, CA: Academic Press), 139, 1-71. doi: 10.1016/bs.agron.2016.05.001

Kuypers, M. M. M., Marchant, H. K., and Kartal, B. (2018). The microbial nitrogen-cycling network. Nat. Rev. Microbiol. 16:263. doi: 10.1038/nrmicro. 2018.9

Kuzyakov, Y., and Xu, X. (2013). Competition between roots and microorganisms for nitrogen: mechanisms and ecological relevance. N. Phytol. 198, 656-669. doi: $10.1111 /$ nph. 12235

Kyveryga, P. M., Blackmer, A. M., Ellsworth, J. W., and Isla, R. (2004). Soil pH Effects on nitrification of fall-applied anhydrous ammonia. Soil Sci. Soc. Am. J. 68, 545-551. doi: 10.2136/sssaj2004.0545

Ladygina, N., Dedyukhina, E. G., and Vainshtein, M. B. (2006). A review on microbial synthesis of hydrocarbons. Process Biochem. 41, 1001-1014. doi: 10.1016/j.procbio.2005.12.007

Le Roux, X., Bouskill, N. J., Niboyet, A., Barthes, L., Dijkstra, P., Field, C. B., et al. (2016). Predicting the responses of soil nitrite-oxidizers to multifactorial global change: a trait-based approach. Front. Microbiol. 7:628. doi: $10.3389 /$ fmicb. 2016.00628

Lehtovirta-Morley, L. E., Ross, J., Hink, L., Weber, E. B., Gubry-Rangin, C., Thion, C., et al. (2016a). Isolation of 'Candidatus Nitrosocosmicus franklandus', a novel ureolytic soil archaeal ammonia oxidiser with tolerance to high ammonia concentration. FEMS Microbiol. Ecol. 92:fiw057. doi: 10.1093/femsec/fiw057

Lehtovirta-Morley, L. E., Sayavedra-Soto, L. A., Gallois, N., Schouten, S., Stein, L. Y., Prosser, J. I., et al. (2016b). Identifying potential mechanisms enabling acidophily in the ammonia-oxidizing archaeon Candidatus "Nitrosotalea devanaterra". Appl. Environ. Microbiol. 82, 2608-2619. doi: 10.1128/AEM.04031-15

Lehtovirta-Morley, L. E., Stoecker, K., Vilcinskas, A., Prosser, J. I., and Nicol, G. W. (2011). Cultivation of an obligate acidophilic ammonia oxidizer from a nitrifying acid soil. Proc. Natl. Acad. Sci. U.S.A. 108, 15892-15897. doi: 10.1073/pnas.1107196108

Leininger, S., Urich, T., Schloter, M., Schwark, L., Qi, J., Nicol, G. W., et al. (2006). Archaea predominate among ammonia-oxidizing prokaryotes in soils. Nature 442, 806-809. doi: 10.1038/nature04983

Li, C. (2007). Quantifying greenhouse gas emissions from soils: Scientific basis and modeling approach. Soil Sci. Plant Nutr. 53, 344-352. doi: 10.1111/j.1747-0765.2007.00133.x

Li, C., Frolking, S., and Frolking, T. A. (1992). A model of nitrous oxide evolution from soil driven by rainfall events: 1 . Model structure and sensitivity. $J$. Geophys. Res. 97, 9759-9776. doi: 10.1029/92JD00509

Li, C., Salas, W., Zhang, R., Krauter, C., Rotz, A., and Mitloehner, F. (2012). Manure-DNDC: a biogeochemical process model for quantifying greenhouse gas and ammonia emissions from livestock manure systems. Nutr. Cycl. Agroecosyst. 93, 163-200. doi: 10.1007/s10705-012-9507-z
Li, Y., Chapman, S. J., Nicol, G. W., and Yao, H. (2018). Nitrification and nitrifiers in acidic soils. Soil Biol. Biochem. 116, 290-301. doi: 10.1016/j.soilbio.2017.10.023

Li, Y., Chen, Z., He, J.-Z., Wang, Q., Shen, C., and Ge, Y. (2019). Ectomycorrhizal fungi inoculation alleviates simulated acid rain effects on soil ammonia oxidizers and denitrifiers in Masson pine forest. Environ. Microbiol. 21, 299-313. doi: 10.1111/1462-2920.14457

Lu, L., and Jia, Z. J. (2013). Urease gene-containing Archaea dominate autotrophic ammonia oxidation in two acid soils. Environ. Microbiol. 15, 1795-1809. doi: 10.1111/1462-2920.12071

Lu, X., Nicol, G. W., and Neufeld, J. D. (2018). Differential responses of soil ammonia-oxidizing archaea and bacteria to temperature and depth under two different land uses. Soil Biol. Biochem. 120, 272-282. doi: 10.1016/j.soilbio.2018.02.017

Ma, B. L., Wu, T. Y., Tremblay, N., Deen, W., Morrison, M. J., McLaughlin, N. B., et al. (2010). Nitrous oxide fluxes from corn fields: on-farm assessment of the amount and timing of nitrogen fertilizer. Glob. Change Biol. 16, 156-170. doi: 10.1111/j.1365-2486.2009.01932.x

Maharjan, B., and Venterea, R. T. (2013). Nitrite intensity explains N management effects on N2O emissions in maize. Soil Biol. Biochem. 66, 229-238. doi: 10.1016/j.soilbio.2013.07.015

Marschner, P. (2011). Marschner's Mineral Nutrition of Higher Plants, 3rd Edn. London: Academic press.

Martens-Habbena, W., and Stahl, D. A. (2011). "Chapter nineteen - nitrogen metabolism and kinetics of ammonia-oxidizing archaea," in Methods in Enzymology, eds M. G. Klotz and L. Y. Stein (San Diego, CA: Academic Press) 496, 465-487. doi: 10.1016/B978-0-12-386489-5.00019-1

McCarty, G. W. (1999). Modes of action of nitrification inhibitors. Biol. Fertil. Soils 29, 1-9. doi: 10.1007/s003740050518

Meier, I. C., Finzi, A. C., and Phillips, R. P. (2017). Root exudates increase N availability by stimulating microbial turnover of fast-cycling N pools. Soil Biol. Biochem. 106, 119-128. doi: 10.1016/j.soilbio.2016.12.004

Menéndez, S., Barrena, I., Setien, I., González-Murua, C., and Estavillo, J. M. (2012). Efficiency of nitrification inhibitor DMPP to reduce nitrous oxide emissions under different temperature and moisture conditions. Soil Biol. Biochem. 53, 82-89. doi: 10.1016/j.soilbio.2012.04.026

Morris, T. F., Murrell, T. S., Beegle, D. B., Camberato, J. J., Ferguson, R. B., Grove, J., et al. (2018). Strengths and limitations of nitrogen rate recommendations for corn and opportunities for improvement. Agron. J. 110, 1-37. doi: 10.2134/agronj2017.02.0112

Motavalli, P. P., Nelson, K. A., and Bardhan, S. (2012). Development of a variablesource $\mathrm{N}$ fertilizer management strategy using enhanced-efficiency $\mathrm{N}$ fertilizers. Soil Sci. 177, 708-718. doi: 10.1097/SS.0b013e31827dddc1

Myrold, D. D., Zeglin, L. H., and Jansson, J. K. (2014). The potential of metagenomic approaches for understanding soil microbial processes. Soil Sci. Soc. Am. J. 78, 3-10. doi: 10.2136/sssaj2013.07.0287dgs

Naz, M. Y., and Sulaiman, S. A. (2016). Slow release coating remedy for nitrogen loss from conventional urea: a review. J. Controll. Release 225, 109-120. doi: 10.1016/j.jconrel.2016.01.037

Nicol, G. W., Leininger, S., Schleper, C., and Prosser, J. I. (2008). The influence of soil $\mathrm{pH}$ on the diversity, abundance and transcriptional activity of ammonia oxidizing archaea and bacteria. Environ. Microbiol. 10, 2966-2978. doi: 10.1111/j.1462-2920.2008.01701.x

Norton, J. M. (2008). "Nitrification in agricultural soils," in Nitrogen in Agricultural Systems, eds J. S. Schepers and W. R. Raun (Madison, WI: American Society of Agronomy, Inc.; Crop Science Society of America, Inc.; Soil Science Society of America, Inc.), 173-199.

Norton, J. M., Klotz, M. G., Stein, L. Y., Arp, D. J., Bottomley, P. J., Chain, P. S. G., et al. (2008). Complete genome sequence of Nitrosospira multiformis, an ammonia-oxidizing bacterium from the soil environment. Appl. Environ. Microbiol. 74, 3559-3572. doi: 10.1128/AEM.02722-07

Norton, J. M., and Stark, J. M. (2011). "Regulation and measurement of nitrification in terrestrial systems," in Research on Nitrification and Related Processes, ed M. G. Klotz (San Diego, CA: Academic Press), 486, 343-368. doi: 10.1016/B978-0-12-381294-0.00015-8

Nowka, B., Daims, H., and Spieck, E. (2015). Comparison of oxidation kinetics of nitrite-oxidizing bacteria: nitrite availability as a key 
factor in niche differentiation. Appl. Environ. Microbiol. 81, 745-753. doi: 10.1128/AEM.02734-14

Opoku, A., Chaves, B., and De Neve, S. (2014). Neem seed oil: a potent nitrification inhibitor to control nitrate leaching after incorporation of crop residues. Biol. Agric. Hortic. 30, 145-152. doi: 10.1080/01448765.2014.885394

Orellana, L. H., Chee-Sanford, J. C., Sanford, R. A., Löffler, F. E., and Konstantinidis, K. T. (2018). Year-round shotgun metagenomes reveal stable microbial communities in agricultural soils and novel ammonia oxidizers responding to fertilization. Appl. Environ. Microbiol. 84, e01646-17. doi: 10.1128/AEM.01646-17

Ouyang, Y. (2016). Agricultural nitrogen management affects microbial communities, enzyme activities, and functional genes for nitrification and nitrogen mineralization. (All Graduate Theses and Dissertations. Logan, UT: Utah State University).

Ouyang, Y., Evans, S. E., Friesen, M. L., and Tiemann, L. K. (2018). Effect of nitrogen fertilization on the abundance of nitrogen cycling genes in agricultural soils: A meta-analysis of field studies. Soil Biol. Biochem. 127, 71-78. doi: 10.1016/j.soilbio.2018.08.024

Ouyang, Y., Norton, J. M., and Stark, J. M. (2017). Ammonium availability and temperature control contributions of ammonia oxidizing bacteria and archaea to nitrification in an agricultural soil. Soil Biol. Biochem. 113, 161-172. doi: 10.1016/j.soilbio.2017.06.010

Ouyang, Y., Norton, J. M., Stark, J. M., Reeve, J. R., and Habteselassie, M. Y. (2016). Ammonia-oxidizing bacteria are more responsive than archaea to nitrogen source in an agricultural soil. Soil Biol. Biochem. 96, 4-15. doi: 10.1016/j.soilbio.2016.01.012

Palomo, A., Pedersen, A. G., Fowler, S. J., Dechesne, A., Sicheritz-Pontén, T., and Smets, B. F. (2018). Comparative genomics sheds light on niche differentiation and the evolutionary history of comammox Nitrospira. ISME J. 12, 1779-1793. doi: 10.1038/s41396-018-0083-3

Park, S., and Ely, R. L. (2009). Whole-genome transcriptional and physiological responses of Nitrosomonas europaea to cyanide: identification of cyanide stress response genes. Biotechnol. Bioeng. 102, 1645-1653. doi: 10.1002/bit.22194

Parton, W. J., Holland, E. A., Del Grosso, S. J., Hartman, M. D., Martin, R. E., Mosier, A. R., et al. (2001). Generalized model for NOx and N2O emissions from soils. J. Geophys. Res. Atmos. 106, 17403-17419. doi: 10.1029/2001JD900101

Patra, A. K., Abbadie, L., Clays-Josserand, A., Degrange, V., Grayston, S. J., Guillaumaud, N., et al. (2006). Effects of management regime and plant species on the enzyme activity and genetic structure of $\mathrm{N}$-fixing, denitrifying and nitrifying bacterial communities in grassland soils. Environ. Microbiol. 8, 1005-1016. doi: 10.1111/j.1462-2920.2006.00992.x

Paustian, K., Easter, M., Brown, K., Chambers, A., Eve, M., Huber, A., et al. (2018). "Field-and farm-scale assessment of soil greenhouse gas mitigation using COMET-Farm," in Precision Conservation: Geospatial Techniques for Agricultural and Natural Resources Conservation, eds J. A. Delgado, G. F. Sassenrath, and T. Mueller (Madison, WI: ASA and CSSA), 341-359.

Paustian, K., Lehmann, J., Ogle, S., Reay, D., Robertson, G. P., and Smith, P. (2016). Climate-smart soils. Nature 532, 49-57. doi: 10.1038/nature17174

Pester, M., Maixner, F., Berry, D., Rattei, T., Koch, H., Lucker, S., et al. (2014). NxrB encoding the beta subunit of nitrite oxidoreductase as functional and phylogenetic marker for nitrite-oxidizing Nitrospira. Environ. Microbiol. 16, 3055-3071. doi: 10.1111/1462-2920.12300

Phillips, R. P., Finzi, A. C., and Bernhardt, E. S. (2011). Enhanced root exudation induces microbial feedbacks to $\mathrm{N}$ cycling in a pine forest under long-term $\mathrm{CO} 2$ fumigation. Ecol. Lett. 14, 187-194. doi: 10.1111/j.1461-0248.2010.01570.x

Placella, S. A., and Firestone, M. K. (2013). Transcriptional response of nitrifying communities to wetting of dry soil. Appl. Environ. Microbiol. 79, 3294-3302. doi: 10.1128/AEM.00404-13

Prosser, J. I., and Nicol, G. W. (2012). Archaeal and bacterial ammonia-oxidisers in soil: the quest for niche specialisation and differentiation. Trends Microbiol. 20, 523-531. doi: 10.1016/j.tim.2012.08.001

Qiao, C. L., Liu, L. L., Hu, S. J., Compton, J. E., Greaver, T. L., and Li, Q. L. (2015). How inhibiting nitrification affects nitrogen cycle and reduces environmental impacts of anthropogenic nitrogen input. Glob. Change Biol. 21, 1249-1257. doi: $10.1111 /$ gcb.12802

Radniecki, T. S., and Lauchnor, E. G. (2011). "Investigating Nitrosomonas europaea stress biomarkers in batch, continuous culture, and biofilm reactors," inMethods in Enzymology, eds G. K. Martin and Y. S. Lisa (San Diego, CA: Academic Press), 217-246. doi: 10.1016/B978-0-12-386489-5.00009-9

Raun, W. R., and Schepers, J. S. (2008). "Nitrogen management for improved use effeciency," in Nitrogen in Agricultural Systems, eds J. S. Schepers and W. R. Raun (Madison, WI: American Society of Agronomy, Inc.; Crop Science Society of America, Inc.; Soil Science Society of America, Inc.), 675-693. doi: 10.2134/agronmonogr49.c17

Robertson, G. P., Bruulsema, T. W., Gehl, R. J., Kanter, D., Mauzerall, D. L., Rotz, C. A., et al. (2013). Nitrogen-climate interactions in US agriculture. Biogeochemistry 114, 41-70. doi: 10.1007/s10533-012-9802-4

Robertson, G. P., Gross, K. L., Hamilton, S. K., Landis, D. A., Schmidt, T. M., Snapp, S. S., et al. (2014). Farming for ecosystem services: an ecological approach to production agriculture. BioScience 64, 404-415. doi: 10.1093/biosci/biu037

Robertson, G. P., and Vitousek, P. M. (2009). Nitrogen in agriculture: balancing the cost of an essential resource. Annu. Rev. Environ. Resour. 34, 97-125. doi: 10.1146/annurev.environ.032108.105046

Rocca, J. D., Hall, E. K., Lennon, J. T., Evans, S. E., Waldrop, M. P., Cotner, J. B., et al. (2015). Relationships between protein-encoding gene abundance and corresponding process are commonly assumed yet rarely observed. ISME J. 9, 1693-1699. doi: 10.1038/ismej.2014.252

Sawyer, J., Nafziger, E., Randall, G., Bundy, L., Rehm, G., and Joern, B. (2006). Concepts and Rationale for Regional Nitrogen Rate Guidelines for Corn. Ames, IA: Iowa State University-University Extension.

Sayavedra-Soto, L., Ferrell, R., Dobie, M., Mellbye, B., Chaplen, F., Buchanan, A., et al. (2015). Nitrobacter winogradskyi transcriptomic response to low and high ammonium concentrations. FEMS Microbiol. Lett. 362, 1-7. doi: 10.1093/femsle/fnu040

Sayavedra-Soto, L. A., Hommes, N. G., Alzerreca, J. J., Arp, D. J., Norton, J. M., and Klotz, M. G. (1998). Transcription of the amoC, amoA and amoB genes in Nitrosomonas europaea and Nitrosospira sp., NpAV. FEMS Microbiol. Lett. 167, 81-88. doi: 10.1111/j.1574-6968.1998.tb13211.x

Schleper, C., and Nicol, G. W. (2010). "Ammonia-oxidising archaea-physiology, ecology and evolution," in Advances in Microbial Physiology, Vol. 57, ed R. K. Poole (London: Academic Press Ltd-Elsevier Science Ltd), 1-41. doi: 10.1016/B978-0-12-381045-8.00001-1

Schlesinger, W. H. (2009). On the fate of anthropogenic nitrogen. Proc. Natl. Acad. Sci. U.S.A. 106, 203-208. doi: 10.1073/pnas.0810193105

Schmidt, E. L. (1982). "Nitrification in soil," in Nitrogen in Agricultural Soils, ed F. J. Stevenson (Madison, WI: American Society of Agronomy), 253-288.

Schroder, J. L., Zhang, H., Girma, K., Raun, W. R., Penn, C. J., and Payton, M. E. (2011). Soil acidification from long-term use of nitrogen fertilizers on winter wheat. Soil Sci. Soc. Am. J. 75, 957-964. doi: 10.2136/sssaj2010.0187

Sedlacek, C. J., McGowan, B., Suwa, Y., Sayavedra-Soto, L., Laanbroek, H. J., Stein, L. Y., et al. (2019). A physiological and genomic comparison of Nitrosomonas cluster 6a and 7 ammonia-oxidizing bacteria. Microb. Ecol. 1-10. doi: 10.1007/s00248-019-01378-8

Shen, T., Stieglmeier, M., Dai, J., Urich, T., and Schleper, C. (2013). Responses of the terrestrial ammonia-oxidizing archaeon $\mathrm{Ca}$. Nitrososphaera viennensis and the ammonia-oxidizing bacterium Nitrosospira multiformis to nitrification inhibitors. FEMS Microbiol. Lett. 344, 121-129. doi: 10.1111/1574-6968.12164

Shi, M., Fisher, J. B., Brzostek, E. R., and Phillips, R. P. (2016). Carbon cost of plant nitrogen acquisition: global carbon cycle impact from an improved plant nitrogen cycle in the Community Land Model. Glob. Change Biol. 22, 1299-1314. doi: 10.1111/gcb.13131

Simkin, S. M., Allen, E. B., Bowman, W. D., Clark, C. M., Belnap, J., Brooks, M. L., et al. (2016). Conditional vulnerability of plant diversity to atmospheric nitrogen deposition across the United States. Proc. Natl. Acad. Sci. U.S.A. 113, 4086-4091. doi: 10.1073/pnas.1515241113

Skiba, M. W., George, T. S., Baggs, E. M., and Daniell, T. J. (2011). Plant influence on nitrification. Biochem. Soc. Transac. 39, 275-8. doi: 10.1042/BST0390275

Smith, P., Martino, D., Cai, Z., Gwary, D., Janzen, H., Kumar, P., et al. (2008). Greenhouse gas mitigation in agriculture. Philos. Transac. 363, 789-813. doi: $10.1098 /$ rstb.2007.2184

Spiertz, J. H. J. (2010). Nitrogen, sustainable agriculture and food security. A review. Agron. Sustain. Dev. 30, 43-55. doi: 10.1051/agro:2008064

Stark, J. M. (1996). Modeling the temperature response of nitrification. Biogeochemistry 35, 433-445. doi: 10.1007/BF02183035 
Stark, J. M., and Firestone, M. K. (1995). Mechanisms for soil-moisture effects on activity of nitrifying bacteria. Appl. Environ. Microbiol. 61, 218-221.

Stark, J. M., and Firestone, M. K. (1996). Kinetic characteristics of ammoniumoxidizer communities in a California oak woodland-annual grassland. Soil Biol. Biochem. 28, 1307-1317. doi: 10.1016/S0038-0717(96)00133-2

Stark, J. M., and Hart, S. C. (1997). High rates of nitrification and nitrate turnover in undisturbed coniferous forests. Nature 385, 61-64. doi: 10.1038/385061a0

Starkenburg, S. R., Arp, D. J., and Bottomley, P. J. (2008). Expression of a putative nitrite reductase and the reversible inhibition of nitrite-dependent respiration by nitric oxide in Nitrobacter winogradskyi Nb-255. Environ. Microbiol. 10, 3036-3042. doi: 10.1111/j.1462-2920.2008.01763.x

Stein, L. Y., Arp, D. J., Berube, P. M., Chain, P. S. G., Hauser, L., Jetten, M. S. M., et al. (2007). Whole-genome analysis of the ammonia-oxidzing bacterium, Nitrosomonas eutropha C91: implications for niche adaptation. Environ. Microbiol. 9, 2993-3007. doi: 10.1111/j.1462-2920.2007.01409.x

Storer, K., Coggan, A., Ineson, P., and Hodge, A. (2018). Arbuscular mycorrhizal fungi reduce nitrous oxide emissions from $\mathrm{N}_{2} \mathrm{O}$ hotspots. N. Phytol. 220, 1285-1295. doi: 10.1111/nph.14931

Subbarao, G. V., Arango, J., Masahiro, K., Hooper, A. M., Yoshihashi, T., Ando, Y., et al. (2017). Genetic mitigation strategies to tackle agricultural GHG emissions: the case for biological nitrification inhibition technology. Plant Sci. 262, 165-168. doi: 10.1016/j.plantsci.2017.05.004

Subbarao, G. V., Sahrawat, K. L., Nakahara, K., Rao, I. M., Ishitani, M., Hash, C. T., et al. (2013). A paradigm shift towards low-nitrifying production systems: the role of biological nitrification inhibition (BNI). Ann. Botany 112, 297-316. doi: $10.1093 / \mathrm{aob} / \mathrm{mcs} 230$

Subbarao, G. V., Yoshihashi, T., Worthington, M., Nakahara, K., Ando, Y., Sahrawat, K. L., et al. (2015). Suppression of soil nitrification by plants. Plant Sci. 233, 155-164. doi: 10.1016/j.plantsci.2015.01.012

Suzuki, I., Dular, U., and Kwok, S. C. (1974). Ammonia or ammonium ion as substrate for oxidation by $\mathrm{N}$. europaea cells and extracts. J. Bacteriol. $120,556-558$.

Taylor, A. E., Giguere, A. T., Zoebelein, C. M., Myrold, D. D., and Bottomley, P. J. (2017). Modeling of soil nitrification responses to temperature reveals thermodynamic differences between ammonia-oxidizing activity of archaea and bacteria. ISME J. 11, 896-908. doi: 10.1038/ismej.2016.179

Taylor, A. E., Zeglin, L. H., Wanzek, T. A., Myrold, D. D., and Bottomley, P. J. (2012). Dynamics of ammonia-oxidizing archaea and bacteria populations and contributions to soil nitrification potentials. Isme J. 6, 2024-2032. doi: 10.1038 /ismej.2012.51

Thapa, R., Chatterjee, A., Awale, R., McGranahan, D. A., and Daigh, A. (2016). Effect of enhanced efficiency fertilizers on nitrous oxide emissions and crop yields: a meta-analysis. Soil Sci. Soc. Am. J. 80, 1121-1134. doi: 10.2136/sssaj2016.06.0179

Thion, C. E., Poirel, J. D., Cornulier, T., De Vries, F. T., Bardgett, R. D., and Prosser, J. I. (2016). Plant nitrogen-use strategy as a driver of rhizosphere archaeal and bacterial ammonia oxidiser abundance. FEMS Microbiol. Ecol. 92:fiw091. doi: 10.1093/femsec/fiw091

Tourna, M., Freitag, T. E., Nicol, G. W., and Prosser, J. I. (2008). Growth, activity and temperature responses of ammonia-oxidizing archaea and bacteria in soil microcosms. Environ. Microbiol. 10, 1357-1364. doi: 10.1111/j.1462-2920.2007.01563.x

Tourna, M., Stieglmeier, M., Spang, A., Könneke, M., Schintlmeister, A., Urich, T., et al. (2011). Nitrososphaera viennensis, an ammonia oxidizing archaeon from soil. Proc. Natl Acad. Sci. U.S.A. 108, 8420-8425. doi: 10.1073/pnas.1013 488108

Trap, J., Bonkowski, M., Plassard, C., Villenave, C., and Blanchart, E. (2016). Ecological importance of soil bacterivores for ecosystem functions. Plant Soil 398, 1-24. doi: 10.1007/s11104-015-2671-6

Treusch, A. H., Leininger, S., Kletzin, A., Schuster, S. C., Klenk, H. P., and Schleper, C. (2005). Novel genes for nitrite reductase and Amo-related proteins indicate a role of uncultivated mesophilic crenarchaeota in nitrogen cycling. Environ. Microbiol. 7, 1985-1995. doi: 10.1111/j.1462-2920.2005. 00906.x

USDA, ERS (2018). United States Department of Agriculture. Available online at: https://www.ers.usda.gov/data-products/fertilizer-use-and-price.aspx (accessed December 23, 2018).
Van Groenigen, J. W., Huygens, D., Boeckx, P., Kuyper, T. W., Lubbers, I. M., Rütting, T., et al. (2015). The soil $n$ cycle: New insights and key challenges. Soil 1, 235-256. doi: 10.5194/soil-1-235-2015

van Kessel, M. A. H. J., Speth, D. R., Albertsen, M., Nielsen, P. H., Op den Camp, H. J. M., Kartal, B., et al. (2015). Complete nitrification by a single microorganism. Nature 528, 555-559. doi: 10.1038/nature16459

Venterea, R. T., Clough, T. J., Coulter, J. A., and Breuillin-Sessoms, F. (2015). Ammonium sorption and ammonia inhibition of nitrite-oxidizing bacteria explain contrasting soil $\mathrm{N} 2 \mathrm{O}$ production. Sci. Rep. 5:12153. doi: $10.1038 /$ srep 12153

Venterea, R. T., and Rolston, D. E. (2000a). Mechanisms and kinetics of nitric and nitrous oxide production during nitrification in agricultural soil. Glob. Change Biol. 6, 303-316. doi: 10.1046/j.1365-2486.2000.00309.x

Venterea, R. T., and Rolston, D. E. (2000b). Mechanistic modeling of nitrite accumulation and nitrogen oxide gas emissions during nitrification. J. Environ. Qual. 29, 1741-1751. doi: 10.2134/jeq2000.00472425002900060003x

Veresoglou, S. D., Chen, B., and Rillig, M. C. (2012). Arbuscular mycorrhiza and soil nitrogen cycling. Soil Biol. Biochem. 46, 53-62. doi: 10.1016/j.soilbio.2011.11.018

Veresoglou, S. D., Sen, R., Mamolos, A. P., and Veresoglou, D. S. (2011). Plant species identity and arbuscular mycorrhizal status modulate potential nitrification rates in nitrogen-limited grassland soils. J. Ecol. 99, 1339-1349. doi: 10.1111/j.1365-2745.2011.01863.x

Veresoglou, S. D., Verbruggen, E., Makarova, O., Mansour, I., Sen, R., and Rillig, M. C. (2018). Arbuscular mycorrhizal fungi alter the community structure of ammonia oxidizers at high fertility via competition for soil NH4+. Microbial Ecol. 78, 147-158. doi: 10.1007/s00248-018-1281-2

Verhagen, F. J., and Laanbroek, H. J. (1991). Competition for ammonium between nitrifying and heterotrophic bacteria in dual energy-limited chemostats. Appl. Environ. Microbiol. 57, 3255-3263.

Verhagen, F. J. M., Hageman, P. E. J., Woldendorp, J. W., and Laanbroek, H. J. (1994). Competition for ammonium between nitrifying bacteria and plant roots in soil in pots; effects of grazing by flagellates and fertilization. Soil Biol. Biochem. 26, 89-96. doi: 10.1016/0038-0717(94)90199-6

Wallenstein, M. D., and Hall, E. K. (2012). A trait-based framework for predicting when and where microbial adaptation to climate change will affect ecosystem functioning. Biogeochemistry 109, 35-47. doi: 10.1007/s10533-011-9641-8

Webster, G., Embley, T. M., Freitag, T. E., Smith, Z., and Prosser, J. I. (2005). Links between ammonia oxidizer species composition, functional diversity and nitrification kinetics in grassland soils. Environ. Microbiol. 7, 676-684. doi: $10.1111 / j .1462-2920.2005 .00740 . x$

Wessén, E., and Hallin, S. (2011). Abundance of archaeal and bacterial ammonia oxidizers - Possible bioindicator for soil monitoring. Ecol. Indicat. 11, 1696-1698. doi: 10.1016/j.ecolind.2011.04.018

Wessen, E., Nyberg, K., Jansson, J. K., and Hallin, S. (2010). Responses of bacterial and archaeal ammonia oxidizers to soil organic and fertilizer amendments under long-term management. Appl. Soil Ecol. 45, 193-200. doi: 10.1016/j.apsoil.2010.04.003

Woodward, E. E., Hladik, M. L., and Kolpin, D. W. (2016). Nitrapyrin in Streams: The first study documenting off-field transport of a nitrogen stabilizer compound. Environ. Sci. Technol. Lett. 3, 387-392. doi: 10.1021 /acs.estlett.6b00348

Xia, L., Lam, S. K., Chen, D., Wang, J., Tang, Q., and Yan, X. (2017). Can knowledge-based $\mathrm{N}$ management produce more staple grain with lower greenhouse gas emission and reactive nitrogen pollution? A meta-analysis. Glob. Change Biol. 23, 1917-1925. doi: 10.1111/gcb.13455

Xia, W. W., Zhang, C. X., Zeng, X. W., Feng, Y. Z., Weng, J. H., Lin, X. G., et al. (2011). Autotrophic growth of nitrifying community in an agricultural soil. Isme J. 5, 1226-1236. doi: 10.1038/ismej.2011.5

Xiang, X., He, D., He, J.-S., Myrold, D. D., and Chu, H. (2017). Ammoniaoxidizing bacteria rather than archaea respond to short-term urea amendment in an alpine grassland. Soil Biol. Biochem. 107, 218-225. doi: 10.1016/j.soilbio.2017.01.012

Xiao, H., Griffiths, B., Chen, X., Liu, M., Jiao, J., Hu, F., et al. (2010). Influence of bacterial-feeding nematodes on nitrification and the ammoniaoxidizing bacteria (AOB) community composition. Appl. Soil Ecol. 45, 131-137. doi: 10.1016/j.apsoil.2010.03.011 
Yao, H., Campbell, C. D., Chapman, S. J., Freitag, T. E., Nicol, G. W., and Singh, B. K. (2013). Multi-factorial drivers of ammonia oxidizer communities: evidence from a national soil survey. Environ. Microbiol. 15, 2545-2556. doi: 10.1111/1462-2920.12141

Yao, H., Gao, Y., Nicol, G. W., Campbell, C. D., Prosser, J. I., Zhang, L., et al. (2011). Links between ammonia oxidizer community structure, abundance, and nitrification potential in acidic soils. Appl. Environ. Microbiol. 77, 4618-4625. doi: 10.1128/AEM.00136-11

Zhang, X., Davidson, E. A., Mauzerall, D. L., Searchinger, T. D., Dumas, P., and Shen, Y. (2015). Managing nitrogen for sustainable development. Nature 528, 51-59. doi: 10.1038/nature15743

Zhu, T., Yang, C., Wang, J., Zeng, S., Liu, M., Yang, J., et al. (2018). Bacterivore nematodes stimulate soil gross $\mathrm{N}$ transformation rates dependingon their species. Biol. Fertil. Soils 54, 107-118. doi: 10.1007/s00374-017 $1244-7$

Conflict of Interest Statement: The authors declare that the research was conducted in the absence of any commercial or financial relationships that could be construed as a potential conflict of interest.

Copyright $\odot 2019$ Norton and Ouyang. This is an open-access article distributed under the terms of the Creative Commons Attribution License (CC BY). The use, distribution or reproduction in other forums is permitted, provided the original author(s) and the copyright owner(s) are credited and that the original publication in this journal is cited, in accordance with accepted academic practice. No use, distribution or reproduction is permitted which does not comply with these terms. 